\title{
Leiders en informatiesystemen
}

Citation for published version (APA):

Mulder, T. J. (1990). Leiders en informatiesystemen. Academic Service.

https://doi.org/10.26481/spe.19900907tm

Document status and date:

Published: 07/09/1990

DOI:

10.26481/spe.19900907tm

Document Version:

Publisher's PDF, also known as Version of record

\section{Please check the document version of this publication:}

- A submitted manuscript is the version of the article upon submission and before peer-review. There can be important differences between the submitted version and the official published version of record.

People interested in the research are advised to contact the author for the final version of the publication, or visit the DOI to the publisher's website.

- The final author version and the galley proof are versions of the publication after peer review.

- The final published version features the final layout of the paper including the volume, issue and page numbers.

Link to publication

\footnotetext{
General rights rights.

- You may freely distribute the URL identifying the publication in the public portal. please follow below link for the End User Agreement:

www.umlib.nl/taverne-license

Take down policy

If you believe that this document breaches copyright please contact us at:

repository@maastrichtuniversity.nl

providing details and we will investigate your claim.
}

Copyright and moral rights for the publications made accessible in the public portal are retained by the authors and/or other copyright owners and it is a condition of accessing publications that users recognise and abide by the legal requirements associated with these

- Users may download and print one copy of any publication from the public portal for the purpose of private study or research.

- You may not further distribute the material or use it for any profit-making activity or commercial gain

If the publication is distributed under the terms of Article $25 \mathrm{fa}$ of the Dutch Copyright Act, indicated by the "Taverne" license above, 
Leiders en informatiesystemen 



\section{Leiders en informatiesystemen}

Rede in verkorte vorm uitgesproken bij de aanvaarding van het ambt van bijzonder hoogleraar in de Bestuurlijke Informatiekunde aan de Faculteit der Economische Wetenschappen van de Rijksuniversiteit Limburg te Maastricht op vrijdag 7 september 1990

Th. J. Mulder

\section{> ACADEMIC SERVICE}


Mulder, "Th.].

Leiders en informatiesystemen / Th. J. Mulder. - Schoonhoven : Acadennic Service Oratie gehouden op 7 sept 1990 aan de Rijksuniversireit Limburg, Maastricht. Mer lir. opg.

ISBN 90-6233-621-3

SISO 521.2 UDC 65.012.4:681.3(042.5) NUGI 852

Trefw: management en informatiesystemen.

Uitgegeven door: Academic Service

Postbus 81

2870 AB Schoonhoven

Zetwerk binnenwerk: Perfect Service, Schoonhoven

Omslagontwerp: Image Consult, Wassenaar

Fongrafie omslag: David Jeffrey

Druk omslag: Drukkerij Veldwijk, Waddinxveen

Druk binnenwerk: Krips Repro, Meppel

Bindwerk: Meeuwis, Amsterdam

Copyright (6) 1990 Th.J. Mulder

ISBN 9062336213

NUGil 852

Niers uit deze uirgave mag worden verweelvoudigd en/of openbar gemaakt door middel wan druk, fotokopie, microflm, geluidsband, elektronisch of op welke andere wijze ook en evenmin in een rerrieval system worden opgeslagen zonder vooratgaande scluriftelijke toestemming van de uitgever. 


\section{Inhoud}

Inleiding 7

1 Leiders 9

1.1 Ondernemers, aanvoerders en beheerders 9

1.1.1 Profiel van de ondernemer 10

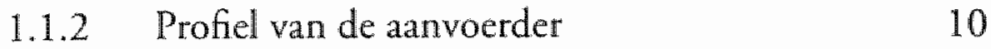

1.1.3 Profiel van de beheerder 11

1.1.4 Profiel van de 'combi-'leider 11

$\begin{array}{ll}1.1 .5 & \text { Leiderschapstijlen } \\ 1.2\end{array}$

1.2 Goede en slechte leiders 13

1.3 Ook het мкв heeft leiders 15

2 Leiders en informatiebehoefte 16

2.1 Infonullen, infofielen en infonaten 16

$\begin{array}{ll}2.2 & \text { Leiderstype en informatiebehoefte } \\ 2.2\end{array}$

2.2.1 Leiderschapstijl en informatiebehoefte 19

2.2.2 Significante karaktereigenschappen en

2.2.3 Relatie tussen leider en organisatie 22

2.2.4 Bepalen van de informatiebehoefte van leiders 24

2.3 Betrokkenheid leiders bij informatiesystemen 27

2.3.1 Type informatiesystemen 28

2.4 Leiders en hun eigen informatiesystemen 33

2.4.1 Management informatiesystemen (MIs) 34

2.4.2 Executieve informatiesystemen (EIS) 35

2.4.3 Beslissingsondersteunende

2.4.4 Persoonlijke informatiesystemen $\quad 37$

2.5 MKв-leiders en informatiesystemen 38 
$3 \quad$ Informatie- en automatiseringsbeleid 41

3.1 Bestuurlijke informatiekunde 41

3.2 Aanpak in (zeer) grote ondernemingen 44

3.2.1 Informatietechnologie 45

3.2.2 Machtsdriehoek 46

3.2.3 Portfolio-analyse 47

3.3 Aanpak in kleine ondernemingen 48

3.3.1 ToBr-methode 50

3.3.2 Wie gaat het MkB helpen? 55

Afsluiting $\quad 60$

Geraadpleegde literatuur $\quad 63$

$\begin{array}{ll}\text { Noten } & 66\end{array}$ 


\section{Inleiding}

Het doel van deze oratie is meer aandacht te vragen voor de bijzondere positie van leiders met betrekking tot informatiesystemen, zowel systemen die organisaties nodig hebben als meer in het bijzonder de informatiesystemen die van belang zijn voor leiders zelf. Er wordt ingegaan op de stelling dat er een verband bestaat tussen de persoonlijkheidsstructuur van een leider en zijn informatiebehoefte.

Vanuit die gedachte is het ontwikkelen van informatiesystemen voor leiders niet alleen een onderwerp voor informatiekundigen, maar ook voor gedragswetenschappers en organisatiedeskundigen.

Wie studenten opleidt voor managementfuncties dient zich te realiseren dat deze studenten eerst na zo'n tien jaar als zodanig gaan functioneren. Zij leven dan in de 2 le eeuw. In die tijd zullen veel omstandigheden gewijzigd zijn. Zij zullen meer dan ooit te maken hebben met geautomatiseerde informatiesystemen voor hun organisaties en voor zichzelf. Dat geldt zowel voor grote als voor kleine bedrijven.

Niet alleen daarom is het onderwerp van deze oratie belang. rijk. Naar verwachting gaat de ontwikkeling van organisaties in de komende jaren in de richting van opsplitsing van ondernemingen in kleinere, min of meer zelfstandige eenheden. Verder bestaat de verwachting dat de toekomstige organisaties platter zullen worden door verdwijnende echelons, die zich nu voornamelijk bezighouden met het verzamelen van informatie en her samenstellen wan rapporten. Deze schakelfuncties zullen op den duur overgenomen kunnen worden door 
informatiesystemen. Dat betekent ook dat er naar werwachting in de 2le eeuw meer leiders van organisaties en minder chefs actief zullen zijn dan in deze eeuw (Drucker, 1987; Schein, 1989). 


\section{Leiders}

\subsection{Ondernemers, aanvoerders en beheerders}

Het woord 'leider' wordt in deze oratie gebruikt als verzamelnaam voor verschillende typen leidinggevende functionarissen, zoals ondernemers, directeuren, raden van bestuur, chief executive officers (CEO's), presidenten, managers, enzovoort. Allemaal verschillende woorden, die samengevat kunnen worden onder her begrip 'leider', hoewel al deze functies, welke naam zij ook hebben, niets zeggen over de taken, bevoegdheden, verantwoordelijkheden en de manier waarop leiders die taken, bevoegdheden en verantwoordelijkheden hanteren. Dit onderwerp is onder meer interessant, omdat deze mensen in hoge mate bepalen wat er gebeurt in de maatschappij. $\mathrm{Zij}$ kunnen vaak nieuwe ontwikkelingen bevorderen of tegenhouden. Dat geldt ook op het gebied van informatiesystemen. In de literatuur is het een geliefkoosd onderwerp uit te diepen welke uiteenlopende typen leiders er bestaan. Zo is langzamerhand meer inzicht ontstaan in leiders en leiderschapstijlen.

Laten we eens kijken naar verschillende typen leiders, zoals ondernemers, aanvoerders en beheerders, daarna naar de informatic en informatiesystemen die zij nodig hebben en vervolgens naar de bestuurlijke aspecten om dit te realiseren. Er wordt hier alleen ingegaan op het bedrijfsleven en niet op overheidsorganisaties. Daarbij worden wat kantrekeningen gemaakt over verschillen tussen grote ondernemingen en het Midden- en Kleinbedrijf (мкв). 


\subsubsection{Profiel van de ondernemer}

Anton Dreesmann geeft in zijn lezing 'Entrepreneurship and leadership' (1985, Saint Gallen) aan dat het bij ondernemers niet alleen gaat om zaken als groei en het nemen van risico's, hoewel dat zeker belangrijke punten zijn die een ondernemer typeren. De bereidheid om onzekerheden te accepteren speelt volgens hem een grotere rol. Hij gaat zelfs verder door te stellen dat juist achter die onzekerheden kansen verborgen zirten.

Ondernemers vertonen een merkwaardig gedrag: zij zoeken naar onzekerheden in plaats van deze te vermijden. Vaak zijn ondernemers erg technologisch gedreven. Zij kennen hun produkten en/of diensten door en door en staan in de eerste levensfase van de onderneming aan de wieg van de innovaties.

\subsubsection{Profiel van de aanvoerder}

De aanvoerder heeft er plezier in met mensen om te gaan en is niet alleen in hun werk of hun produktie geinteresseerd; hij heeft een sterk ontwikkeld gevoel voor communicatie en sociale situaties. Hij of zij is een bron van inspiratie voor anderen. Hij is creatief en charismatisch. Charisma is een gevolg van succesvolle creativiteit. Er is altijd sprake van her element van 'richting geven'.

Een aanvoerder heeft de capaciteit algemene doelen en behoeften aan te voelen en is in staat gevoelens en energie bij zijn medewerkers te mobiliseren. 


\subsubsection{Profiel van de beheerder}

Een beheerder is een leider die risico's mijdt. Een voorbeeld van een beheerder, bepaald geen ondernemer of aanvoerder, is de kapitein van een cruiseschip of de gezagvoerder van een Jumbo 747. Sommige auteurs maken het nog erger. Zij gebruiken metaforen als steward en buschauffeur. In die visie zijn de volgelingen van de leider slechts passagiers, die meerijden tot de halte waarop zij het wellerjes vinden. Een kapitein van een cruiseschip runt het schip niet, dat doet zijn maatschappij. Die bepaalt de koers. Dit is wat anders dan de ondernemer of aanvoerder die zijn eigen boot bouwt en bepaalt wat er mee gebeurt. Nietremin zijn er wel degelijk siltuaties waarin ondernemingen (cijdelijk) gebaat zijn met een beherende leider, met name in omstandigheden waarin het gaat om overleven in een markt waarin het maken van een fout dodelijk kan zijn.

\subsubsection{Profiel van de 'combi-'leider}

Ondernemers zijn doelgericht, aanvoerders mensgericht en beheerders rolgericht. Mensen zijn echter zelden uitsluirend het een of het ander. Er is vaak sprake van een ingewikkelde mengeling van eigenschappen van 'ideale' typen. Kotter (1982 en 1990) maakt onderscheid in leiders en managers. Leiders vervangen managers niet, maar vullen hen aan. Waar managers te maken hebben met complexiteit, plannen en budgetteren, hebben leiders te maken met veranderen, motiveren en inspireren. Met het woord leider wordt in deze oratie de combinatie aangegeven van de metaforen ondernemer, aanvoerder en beheerder.

Deze 'combi' heeft een brede belangstelling en oog voor details. Door zijn brede belangstelling kunnen bruggen wor- 
den geslagen. Zijn liefde voor details maken hem op bepaalde gebieden een goede gesprekspartner voor de echte deskundigen. Hij heeft toewijding en wilskracht. Openheid is zijn handelsmerk. ${ }^{1}$

\subsubsection{Leiderschapstijlen}

De manier waarop leiders leidinggeven kan sterk verschillen. Hun stijl varieert van collegiaal naar autoritair. Velen zijn het er over eens dat je leidinggeven niet kunt leren uit een boekje. Nietremin is er erg veel gepubliceerd over het fenomeen leidinggeven en leider. Niet alleen wat de taken (zouden moeten) zijn van leiders, maar ook wat hen beweegt leider te worden. Studies waarin leiders gedurende korte of langere tijd worden gevolgd, geven een idee van de globale tijdsbesteding van leiders en met name van de wijze waarop leiding wordt gegeven, de stijl van leidinggeven. In 1965 publiceerden Blake en Mouton hun visie op dit onderwerp. Zij plaatsten doelgericht en mensgericht leiderschap loodrecht op elkaar, elk verdeeld in negen gradaties. Zo ontstonden 81 stijlen van leidinggeven. De beste stijl was naar hun mening als een leider in beide richtingen maximaal scoorde.

Er zijn ook andere opvatringen over de 'beste' stijl van leidinggeven. Handy (1985) onderscheidt naast mens- en taakgerichte leiders ook rol-en machtsgerichte leiders. Deze richtingen vormen een assenkruis met vier quadranten, waarin een bepaald soort leiderschap gepositioneerd kan worden. Overigens is het voor de betreffende leider geen kwestie van kiezen. Zijn stijl is sterk gekoppeld aan zijn karakter. Wat we wel kunnen zeggen, is dat in bepaalde omstandigheden veelal gekoppeld aan de groeifase van een onderneming - de ene stijl de voorkeur verdient boven de andere. Zo is in een tijd van crisis in een bedrijf behoefte aan een sterke en weinig 
democratische leider. In een tijd waarin het de organisatie voor de wind gaat, wordt een democratisch mild leiderschap meer gewaardeerd. Dit brengt sommigen tot de idee dat de beste stijl situationeel leiderschap zou zijn, hetgeen betekent dat de leider zijn stijl aanpast aan de situatie waarin het bedrijf verkeert. Dit is een aanname die maar voor weinig leiders is weggelegd.

Nogmaals, de stijl van een leider is geen keuze, maar grotendeels een gevolg van zijn karakter. Leiders die wel van stijl proberen te wisselen, worden onnatuurlijk en niet meer geloofwaardig geacht (Badaracco Jr, 1989). In de praktijk komt het in de ontwikkeling van een onderneming van klein naar groot vaak voor dat verschillende typen leiders elkaar afwisselen (Clifford, 1986).

Vrijwel alle stijlen kunnen, zij het op tijdelijke basis, succes hebben. Het succes van de stijl duurt zolang als de omgeving van de leider zijn stijl accepteert.

\subsection{Goede en slechte leiders}

In leerboeken wordt meestal uitgegaan van de goede leider, de persoon die voldoet aan alle criteria, een mannetjesputter, iemand die bergen kan verzetten en waar de gemeenschap tegenop ziet. Deze leiders hebben verschillende stijlen van leidinggeven. Elke neutrale stijl heeft echter zijn parhologische varianten. Daar zien we andere leidersbeelden. ledereen weer dat dat soort regeringsleiders bestaan (Amin, Ceausescu, Hitler, Stalin). Er is een breed overgangsgebied van geestelijk gezonde, goed in balans functionerende managers en de werkelijk zieke leiders.

De druk waaronder leiders leven en werken is groot. Door allerlei verklaarbare zaken in het leven van de leider en/of situaties in zijn organisatie, bestaat de mogelijkheid dat lei- 
ders het spoor kwijt raken. Lord Acton raakt wellicht de kern met zijn uitspraak: "Macht verderft en absolute macht verderft absoluut." Dat geldt zowel voor leiders van naties als voor leiders van organisaties. De vraag is wat 'normaal' is. Sommige neurotische leiders met een 'afwijkend' gedrag kunnen toch redelijk functioneren.

Maar zelfs cen zeer gezonde leider is een mens, die verkouden en moe kan worden, die zijn slechte dagen kent, waarin toch verwacht wordt dat hij de inspiratiebron is voor anderen. En als iemand een goede leider is, hoe lang is hij dat dan?

Er is een belangrijk verschil tussen de managementliteratuur en de dagelijkse managementpraktijk. Wij leren elkaar hoe organisaties goed geleid moeten worden. Succesverhalen zijn daarbij in trek, vooral in de Amerikaanse literatuur. ${ }^{2}$

De vergelijking dringt zich op met de medische wetenschappen. Je moet er niet aan denken dat in die opleiding uitsluitend gezonde lichaamsfuncties worden behandeld. Ook in de organisatievakken en in het vak Bestuurlijke Informatiekunde zou daarom meer rekening gehouden moeten worden met het gegeven van onvolkomenheden door bijvoorbeeld het invoeren van een vak als organisatiepathologie. We zouden meer kunnen uitgaan van afwijkende situaties en bekijken hoe(lang) daarmee te leven is.

In de praktijk komt er wroeg of laat een moment waarop de omgeving van de leider zijn gedrag en zijn leiderschap niet meer accepteert. Acceptatie is voor elke leiderschapstijl een voorwarde. Mar wanneer die acceptatie bestaat, zal de organisatie van de leider ook moeten voldoen aan de wensen van de leider terzake van zijn werkomstandigheden. Daaronder valt ook het bepalen van welke informatie hij nodig heeft, ongeacht war informatiekundigen daarvan vinden. 


\subsection{Ook het MKB heeft leiders}

Over het algemeen staan alleen de leiders van volken of grote ondernemingen in de belangstelling. Maar ook het MKB, het type organisatie waaraan hier meer aandacht wordt geschonken, heeft zijn leiders. Kleine organisaties wijken sterk af van grote organisaties (Beek, 1989). Het leiderschap binnen het MKB stelt daarom specifieke eisen. Denk hierbij bijvoorbeeld aan de splitsing van strategische en operationele leiding in grote ondernemingen, die in het MKB veelal in één persoon zijn verenigd.

Als een leider van een grote onderneming zich permitteert operationeel werk te verrichten, wordt dat over het algemeen gezien als een slechte eigenschap. Hij moet zich immers met strategie bezighouden. Operationeel werk verrichten wordt in zijn geval gezien als het verrichten van minder hoogwaardige arbeid. Er zijn ook leiders die dat soort werk niet willen uitvoeren. Vaak gebruiken zij de onsympathieke uitdrukking, dat zij zichzelf daarvoor te duur achten. Uiteraard is dit geen pleidooi om leiders van grote organisaties structureel operationele werkzaamheden te laten uitvoeren. Maar cen leider die zo nu en dan de handen uit de mouwen steekt, geeft een voorbeeld dat heilzaam kan werken in een organisatie.

$V$ an de leider in het MKB verwachten we echter zonder meer dat hij strategisch en operationeel werk weet te combineren. Hij heeft vaak een lagere opleiding en kan niet terugvallen op gespecialiseerde staffunctionarissen.

Binnen het vakgebied Bestuurlijke Informatiekunde willen wij in Maastricht specifiek aandacht besteden aan het Midden- en Kleinbedrijf. Wellicht zou dat ook aanbeveling verdienen bij andere vakken binnen de economie. De relatieve betekenis van het мкв is groeiende. Voor de Rijksuniversiteit Limburg is dit extra belangrijk, omdat deze omgeven is door een scala van dit type bedrijuen. 


\section{Leiders en informatiebehoefte}

\subsection{Infonullen, infofielen en infonaten}

Over verbanden tussen leiderschapstijl en informatiesystemen, maar ook met andere groorheden als organisatiestructuur en -cultuur, is door verschillende onderzoekers gepubliceerd (Kets de Vries, 1988 en 1989; Menting, 1989; Peters, 1988). In het McKinsey 7-S model wordt aandacht gevraagd voor zeven grootheden, die in onderlinge samenhang bepalend zijn voor het succes van (het leidinggeven aan) ondernemingen, te weten Strategie, Systemen, Staf, Significante waarden (cultuur), Structuur, Stijl van leidinggeven en Sleutelvaardigheden. ${ }^{3} \mathrm{Al}$ in 1973 ging Galbraith in zijn boek ${ }^{4} \mathrm{Het}$ ontwerpen van complexe organisaties' in op de relatie tussen informatie(systeem) en organisatiestructuur. De structuur is afhankelijk van de beperkingen van de communicatiekanalen tussen leiders en medewerkers. Als reactie hierop worden in dit boek vier strategieën geformuleerd, die zijn gericht op het verminderen van de informatie of op het vergroten van de capaciteit om informatie te verwerken in een organisatie. Het ontwikkelen van verticale informatiesystemen valt in de laatste categorie.

Er is een verband tussen het typen leider casu quo de leiderschapstijl en de informatie waaraan hij behoefte heeft. Met andere woorden, zelfs in exact dezelfde typen organisaties is er toch verschil in informatiebehoefte aan de top. Bewijzen daarvoor zijn er te over. Bij opvolgingssituaties is één van de 
eerste zaken die verandert, de informatievoorziening van de leider zelf. In grotere organisaties is de invloed van de bestaande cultuur en structuur op de stijl van leidinggeven veel groter dan in kleine organisaties. Naarmate de organisatie kleiner is (bijwoorbeeld enkele honderden medewerkers en minder), is de invloed van de leider op de organisatiestructuur, de cultuur van de onderneming en de informatiesystemen het groorst. In hoeverre de leider van die invloed gebruik makkt om de informatievoorziening voor de organisatie en zichzelf te verbeteren hangt af van zijn affiniteit tot informatie.

Sommige leiders besteden een groot deel van hun tijd aan de verbetering van hun eigen informatievoorziening en die van hun organisatie; anderen voelen zich totaal niet aangetrokken tor deze activiteiten.

Met de woorden infonul, infofiel en infonaat geef ik de mate van affiniteit van een leider aan tor informatie. Infonullen hechten weinig waarde aan informatie, infofielen houden ervan en infonaten overdrijven het belang of maken er misbruik van.

Er bestaat een verband tussen het type leiderschap, de stijl van leidinggeven, significante karaktereigenschappen en de relatie die een leider heeft met zijn organisatie. Op grond van deze verbanden kunnen leiders worden ingedeeld in verschillende informatie-affiniteitscategorieeën.

\subsection{Leiderstype en informatiebehoefte}

De ondernemer onder de leiders gaat uit van de haalbaarheid van zijn plannen. Dat wil niet zeggen dat iedere ondernemer grote waarde hecht aan uitgewerkte ondernemings- en beleidsplannen. Dat is meer de informatiebehoefte van banken en andere financiers. Door hun technische gedrevenheid zul- 
len ondernemers informatie willen hebben over hun produkten en/of diensten waarmee zij zich het meest verbonden achten. De ondernemer is vaak een starter en een doener. Het prototype van de ondernemer is vaak blind voor cijfers over de bedrijfssituatie omdat zijn plan, produkt, onderneming meer een religie is dan een realiteit. Negatieve informatie darover zal hij beschouwen als historische gegevens en dus niet meet up to date en belangrijk. Gegevens op basis van optimistische prognoses liggen meer in zijn lijn. De ondernemer onder de leiders is het minst geinteresseerd in informatie. Veel ondernemers zijn echte infonullen. ${ }^{4}$ Uiteraard moet ook de ondernemer informatie krijgen over de werkelijke gang van zaken, maar deze informatievoorziening zal minder ontwikkeld casu quo gebruikt worden dan bij andere typen leiders.

De aanvoerder is meer geinteresseerd in de activiteiten dan in de bereikte situatie. Deze leiders stellen bijvoorbeeld een verlies- en winstrekening meer op prijs dan een balans.

Aanvoerders hebben grote belangstelling voor externe informatie. Een aanvoerder wil graag zijn visie onder woorden gebracht zien in een beleidsplan. Omdat zijn visie op zijn eigen karakter gestoeld is, zijn er vaak anderen nodig die deze visie in een neutralere vorm moeten gieten. Een aanvoerder zal graag uitgebreide informatie willen ontvangen over zijn mensen. Meer dan wat normaal uit de traditionele personeels- en salarisadministraries beschikbaar komt. Sommige aanvoerders zijn ware infofielen. McArthur staat bekend als een aanvoerder die ontstellend veel informatie paraat had. Onze eigen minister-president Lubbers kan er echter ook wat van. Deze algemeenheden gaan natuurlijk niet voor iedere regeringsleider op. Ex-president Reagan behoort eerder tot de infonullen onder de staatslieden. 
De beheerder onder de leiders richt zich op de situatie waarin het bedrijf zich bevindt. Dit type leider hecht meer waarde aan een balans dan aanvoerders en ondernemers. Vaak zijn beheerders zeer geïnteresseerd in zeer gedetailleerde informatie. Sommige beheerders hebben een te sterk geloof in de informatie die zij in hun organisatie voorgeschoteld krijgen. Zij houden daar zo sterk aan vast, dat zij bestempeld kunnen worden als infonaten. Meer dan de andere typen leiders vallen zij in de valkuil van 'het komt uit ons informatiesysteem, dus her is waar'.

\subsubsection{Leiderschapstijl en informatiebehoefte}

Het ene type leiders behoort vaker tot een affiniteitscategorie dan andere typen. Afhankelijk van de mate van onderverdeling van deze typologie geeft dat maar een grove indeling, die niet op individuele leiders kan worden toegepast. Meer inzicht geven significante karaktereigenschappen van de leider en zijn vrijwel altijd daarop gebaseerde stijl van leidinggeven. Een wantrouwende leider en een goedgelovige leider zullen verschillende eisen stellen aan de informatie die zij nodig achten. Zij zullen zelfs dezelfde informatie op andere wijze interpreteren en daaruit verschillende conclusies trekken. Bepaalde leiderschapstijlen vertonen meer infonulle, infofiele of infonate aspecten dan andere stijlen.

De leiderschapstijlen die meer op macht zijn gericht, zullen vaker infonare kenmerken hebben dan de mensgerichte stijlen.

Leiders die pas willen beslissen nadat 'alle' feiten op tafel liggen en zoveel mogelijk onzekerheden willen uitbannen, erkennen de grote waarde van informatie en informatiesystemen. Accountants zijn meestal zeer infofiel ingesteld. Starreveld raadt in de jaren zeventig bijvoorbeeld aan om als een 
beslissing niet echt moet worden genomen, het dan ook niet te doen. In de tijd die volgt, zou immers meer informatie beschikbaar kunnen komen.

\subsubsection{Significante karaktereigenschappen en informatiebehoefte}

Als de informatiebehoefre van een leider zo sterk gekoppeld is aan zijn leiderschapstijl, moet daar bij de bepaling van de informatiebehoefte meer rekening mee worden gehouden. De stijl is goed te herkennen aan het gedrag van de leider. Het vaststellen van gedrag van leiders is een onderwerp dat spaarzaam voorkomt in informatiekundige opleidingen, laat staan in informatica-opleidingen. In het boek 'Balanceren aan de top' gaan de auteurs Manfred Kets de Vries en Danny Miller in op de persoonlijkheid van de leider en de invloed daarvan op de organisatie. ${ }^{5}$ Die is uitermate groot.

Een leider is in staat om in vrij korte tijd zijn stempel, dat wil zeggen zijn karakter, te drukken op een onderneming. In het boek wordt ingegaan op (veel?) voorkomend afwijkend gedrag van leiders. Afwijkend van wat er van een manager verwacht kan worden, die handelt volgens economische principes. Enkele prototypen passeren hierna kort de revue. Het gaat om de dramatische, achterdochtige, afstandelijke, depressieve en dwingende leiders. Daarbij wordt geen waarde-oordeel gegeven over deze leiders, die onder bepaalde omstandigheden grote successen kunnen boeken.

\section{Infonulle leiders}

De dramatische leider met zijn behoefte aan grandeur, aandacht, acriviteit, opwinding, stimulering en onconventionele 
risico's behoort tot de infonullen. Intuïtie zegt hem meer dan feitenmateriaal.

De afsiandelijke leider leeft in een isolement en heeft weinig interesse in de lopende en toekomstige gebeurtenissen. In feite is er in dit geval sprake van een machtsvacuüm. Deze leider is absoluut een infonul.

De depressieve leider koestert een angst voor hervormingen. Hij heeft een gebrek aan eigenwaarde en duldt mislukkingen en middelmatigheid. Ook deze leider is een infonul. Zijn organisatie houdt zich zelden bezig met het verzamelen van informatie, zodat ook andere leidinggevende functionarissen de informatie mislopen om passende maatregelen te nemen.

\section{Infonate leiders}

De achterdochtige leider is een infonaat. Informatie is de centrale machtsbron. Hoe meer informatie, hoe meer hij opgewassen is tegen de bedreigingen. Achterdochtige leiders zijn alert en altijd bereid om te vechten. Hun achtervolgingswaan leidt tot een 'bunkermentaliteit'. Hun hang naar informatie is vaak de oorzaak van het tot stand komen van goed ontwikkelde informatiesystemen.

De dwingende leider will zijn organisatie van onder tot boven beheersen. Spontaniteit is bij hem ver te zoeken. Deze leider is een infonaat. Hij heeft een obsessie voor regels, details, procedures, orde en efficiency. Kenmerk van dwingende organisaties is onder andere het voorkomen van uitgebreide informatiesystemen. 


\subsubsection{Relatie tussen leider en organisatie}

Een aanknopingspunt om het gedrag van leiders te analyseren is te kijken naar hun relatie met de eigen organisatie.

Toen de 88-jarige voorzitter van de Raad van Bestuur van Matsushita Electronica gevraagd werd naar zijn belangrijkste taak aarzelde hij geen moment: "Ik belichaam de liefde. Ik ben de ziel van de onderneming" (Blanchard, 1988).

De relatie van een leider met zijn bedrijf is uit te drukken in termen van liefdestelaties. Een dergelijke relatie komt dichter bij de werkelijkheid dan in zakelijke bewoordingen is weer te geven. De aard van de relatie geeft de houding van de leider ten opzichte van informatie van zijn organisatie aan.

\section{Infonulle relaties}

De intense, opofferende liefde: in deze situatie stelt de leider zijn bedrijf op een hoger plan dan zijn gezondheid en zijn huwelijk. Sommige leiders verkiezen zelfs liever de dood dan getuige te zijn van de afgang of ondergang van hun onderneming, leger of beweging. Objectieve informatie over de organisatie is nauwelijks mogelijk. Deze liefde maakt blind (voor informatie).

\section{Infofiele relaties}

Het bouden van: een harmonieuze relatievorm tussen leider en onderneming. In deze toestand is het logisch dat de leider zich inspanningen en opofferingen getroost, die objectief zakelijk gezien niet gevraagd mogen worden. Toch kan er in deze relatievorm een open oog zijn voor informatie over de organisatie. 
Het verstandshwwelijk: dit betekent in het zakelijke equivalent een weinig inspirerende relatie, die uit noodzaak of gewoonte wordt voortgezet. Deze relatie wordt meer bij beheerders dan bij ondernemers en aanvoerders aangetroffen.

\section{Infonate relaties}

De egoistische relatie:in dit geval houdt de leider vooral van zichzelf. Onverschilligheid ten opzichte van de belangen van de organisatie voert de boventoon. Informatie van of over de organisatie wordt soms aangepast aan het eigenbelang van de leider.

De haatrelatie: helaas komt ook deze relatie voor. In deze situatie kunnen leiders ertoe overgaan informatie te misbruiken om de organisatie schade toe te brengen.

Relarievormen tussen leiders en organisaries geven een indicatie over behoefte en gebruik van informatie.

Het zal duidelijk zijn dat gedrag van leiders in verschillende relatievormen niet altijd is gebaseerd op het handelen in het belang van zijn organisatie. Wie alleen vanuit een rationele en economische invalshoek probeert besluiten van leiders te begrijpen, bekijkt maar een deel van de realiteit. 
(vereenvoudigd voorbeeld)

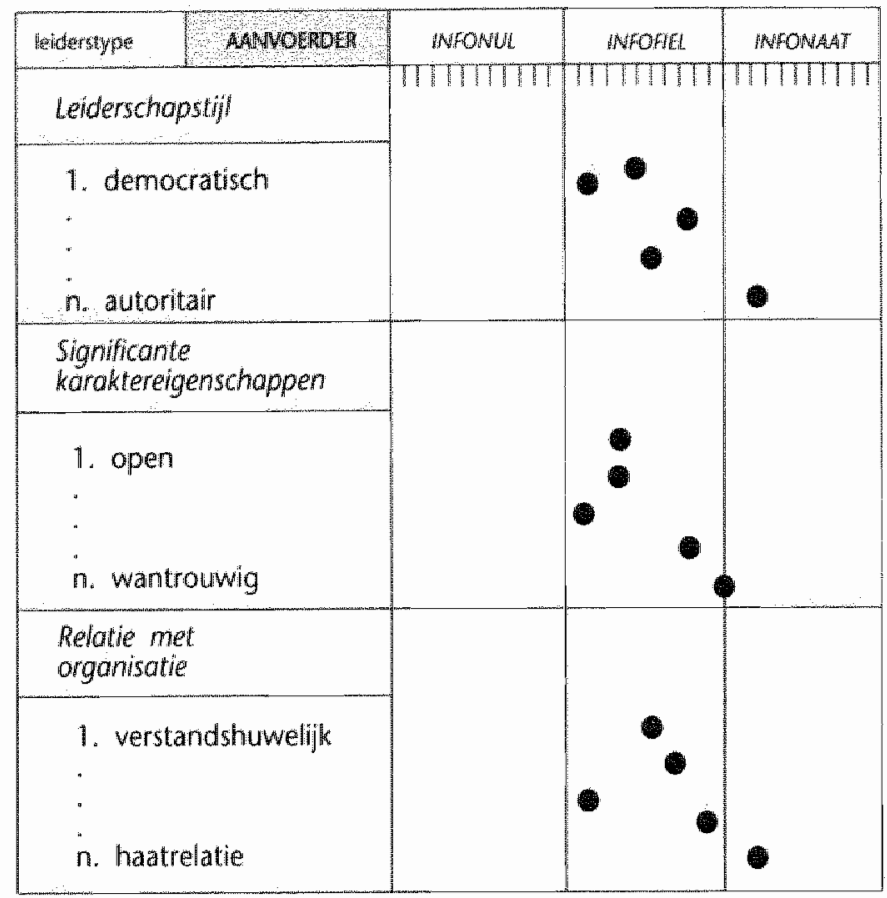

Figuur 1: Bepaling affiniteit tot informatie

\subsubsection{Bepalen van de informatiebehoefte van leiders}

Als we precies zouden weten wat leiders doen, zou her eenvoudig zijn voor hen de juiste informatie te verzamelen. Helaas weten we nog niet (voldoende) welke activiteiten leiders in de uitvoering van hun functie precies uitvoeren (Kotter, 1982; Mintzberg, 1973). ${ }^{6}$

Her is een bekend feit dat leiders ook niet volledig en juist en zeker niet gestructureerd hun eigen informatiebehoefte kunnen formuleren. 'Toch is het geen goede zaak als informatie- 
analisten op eigen houtje gaan bepalen welke informatie een leider nodig heeft. Er zijn voldoende argumenten om aan te nemen dat de meesten dat ook niet kunnen. De aandacht richt zich dus op het vinden van een methode, die de informatiebehoefte van leiders goed op een rijtje krijgt. Deze methode bestaat naar mijn weten nog niet.? Wel zijn er magere resultaten te melden op het gebied van het formuleren van informatiebeleid en informatieplanning. Topics daarbij zijn cle relatie met het ondernemingsbeleid en het bewerkstelligen van een verbetering van de concurrentiepositie (Van Dissel en Park, 1989).

Informatiesystemen voor leiders moeten worden gebouwd op basis van de informatiebehoefte van die leiders. Die behoefte wordt meestal verbaal uitgedrukt. Het is al een hele toer om deze wensen op een fundamentele manier te verwerken tot gestructureerde modellen, die op hun beurt weer uitgangspunt zijn woor computerverwerking. Wij onderwijzen in Maastricht een methode die dit wetenschappelijk verantwoord ondersteunt en tevens (het gebrek aan) de consistentie van de wensen kan aantonen (Nijssen, 1989; Dietz, 1990). Waar in deze oratie de nadruk op gelegd wordt, is het feit dat de leiding in de formulering van haar eigen informatiebehoefte soms onjuist en altijd onvolledig is en dat deze zeker niet verstrekt kan worden in de vorm waarin informatie-analisten dat momenteel wensen. Door meer te weten van de persoon wan de leider kunnen deze lacunes misschien aan het licht worden gebracht en kunnen informatiesystemen worden ontwikkeld waarmee leiders beter uit de voeten kunnen. De leiderschapstijl bepaalt in hoge mate de gevoelde informatiebehoefte van een leider. De stijl is een afgeleide van zijn persoonlijkheidsstructuur. Die structuur komt (vermomd) tot uiring in her gedrag ten opzichte van de organisatie.

Zowel de organisatie, de leider als de informatiedeskundige zullen er baat bij hebben, als de leider in het kader van de be- 
paling van de informatiebehoefte een psycho-analytisch onderzoek alsmede een onderzoek waarin zijn relatie met zujn organisatie wordr geanalyseerd, zou willen ondergaan (zie figuur 2).

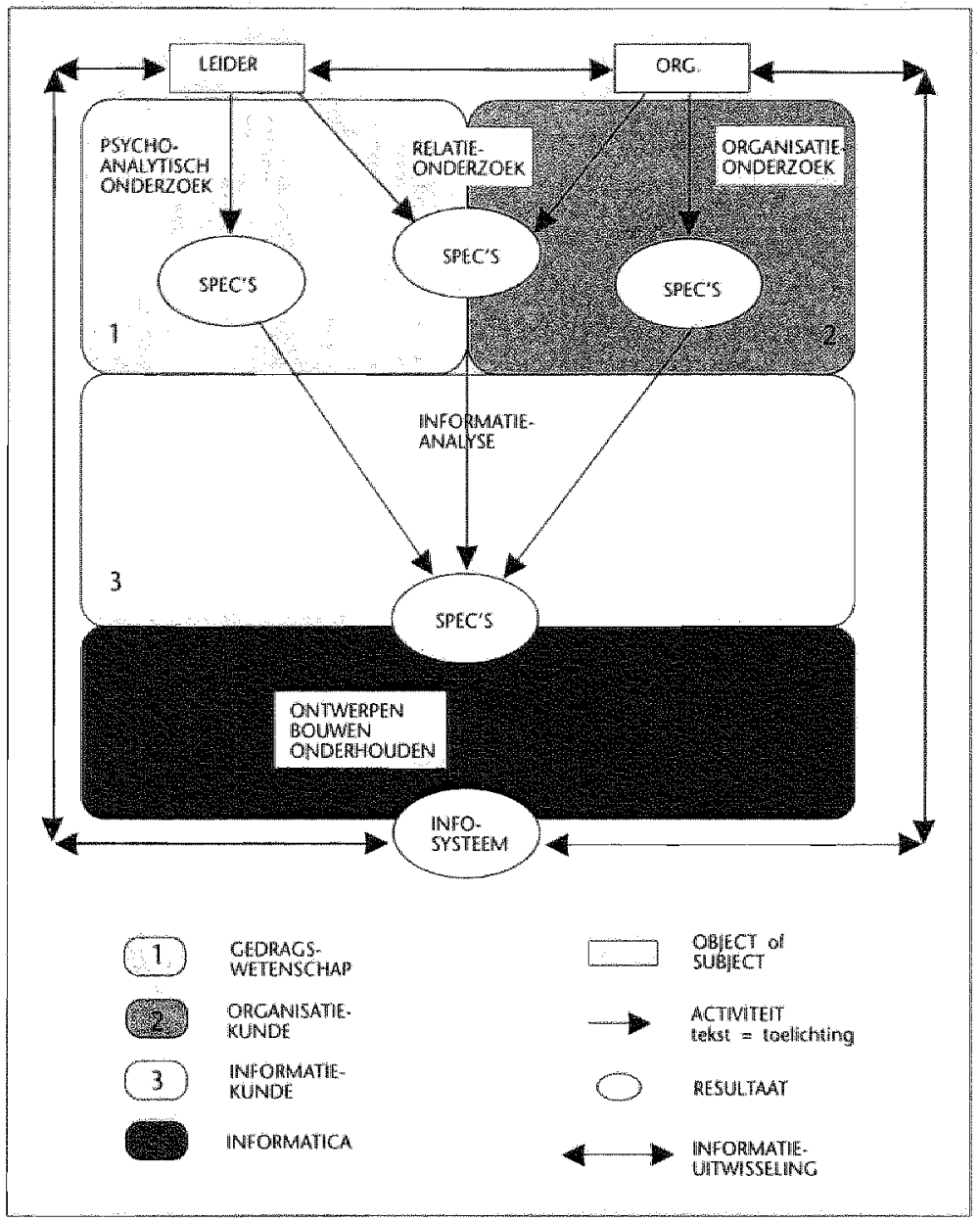

Figuur 2: Positionering onderzoeken, die leiden tot specificaties van management support systemen 
Daaruit zou naar voren kunnen komen hoe een leider werkelijk naar informatie kijkt. Zolang een leider geaccepteerd wordt, is zijn zelfgevoelde informatiebehoefte hét uitgangspunt voor de opzet van zijn eigen informatievoorziening. Dat laat onverlet dat goede informatie-analisten leiders best kunnen wijzen op het nut van andere informatie voor het besturen van de organisatie.

\subsection{Betrokkenheid leiders bij informatiesystemen}

De relatie informatiesystemen en leiders heeft twee kanten. Eén kant is de bijdrage van de hoogste leiding in de totstandkoming van informatiesystemen voor de organisatie. De andere kant is de organisatie van informatievoorziening puur voor de leider zelf. Voor een beperkt deel maar komt die 'persoonlijke' informatie uir informatiesystemen die voor een organisatie als geheel nodig zijn.

Ook die "persoonlijke" informatie is voor een deel te systematiseren en daarom met een computer goed te ondersteunen. Die systemen zullen sterk afhangen van zijn werkwijze en zijn leiderschapstijl. De rol die de leider speelt bij de informatiesystemen voor de hele organisatie, is uitermate belangrijk. Uit verschillende onderzoeken ${ }^{8}$ is naar voren gekomen dat betrokkenheid van de hoogste leiding doorgaans positief werkt op de resultaten van het automatiseren van informatiesystemen (Riesewijk, 1990).

Op zichzelf is dat geen opzienbarende uitkomst. Als de hoogste leiding meer aandacht krijgt voor personeelszaken of verkoop, zal dat in zijn algemeenheid ook wel een positieve uitwerking hebben.

De vraag is: hoeveel tijd moet een topmanager besteden aan informatiesystemen in concurrentie met bijvoorbeeld marketing en produktie. Het antwoord is dat er meer tijd besteed 
moet worden naarmate automatisering van informatiesystemen meer strategisch van aard is (Cash Jr, 1988). In de jaren ' 60 en " 70 vonden we alle informatiesystemen strategisch. Specialisten reisden toen het land door om managers onder meer op de hoogte te stellen van de betekenis van de gatjes in ponskaarten. Op dit moment denken we daar genuanceerder over. We hebben nu instrumenten om te onderzoeken hoe belangrijk informatiesystemen zijn voor organisaties. Als zowel de huidige als de toekomstige informatiesystemen strategisch niet belangrijk zijn, kan het management zich gerust permitteren deze tak van sport an anderen in de organisatie over re laten. Deze keuze heeft een MKB-leider overigens praktisch niet om de simpele reden dat er weinig anderen in zijn organisatic aanwezig zullen zijn aan wie hij deze taak kan overdragen. De situatie kan verbeteren wanneer op den duur de medewerkers in her MKB een daarop afgestemde informatica-en informatiekundige-opleiding hebben genoten. Als het automatiseren wan informatiesystemen wel strategisch is, moet de leider wel in actie komen om het belang daarvan extra te onderstrepen.

Afhankelijk van de grootte van de organisatie varieert dit van het optreden als woorzitter van een stuurgroep Automatisering tot het aanstellen van een lid wan de Raad van Bestuur met de portefeuille 'Informatie".

\subsubsection{Typen informatiesystemen}

Welke informatiesystemen worden in organisaties gebruikt en zijn deze van belang zijn voor leiders?

Informatiesystemen kunnen op verschillende manieren worden onderscheiden. Indelingscriteria zijn bijvoorbeeld: doel, vorm en gebruiker. $\mathrm{Om}$ een oordeel te hebben over het belang voor de onderneming zouden leiders in ieder geval enig 
inzicht in informatiesystemen voor hun organisaties moeten hebben.

Informatiesystemen die voornamelijk voor leiders zijn bestemd, worden in de volgende paragraaf behandeld.

\section{Transactiegerichte informatiesystemen}

Het is moeilijk zonder meer te stellen welke geautomatiseerde, operationele informatiesystemen organisaties in het algemeen nodig hebben. We kunnen wel stellen dat ieder bedrijf een personeelsinformatiesysteem nodig heeft, maar als het gaat om een eenmanszaak is dat overdreven.

Bij geautomatiseerde informatiesystemen moet er wel sprake zijn van enige omvang. Vroeger moest die omvang massaal zijn om economisch verantwoord te automariseren. Tegenwoordig is een omvang van enkele mutaties per week al voldoende aanleiding de computer in te schakelen.

Vanuit informatiekundig opzicht heeft het weinig zin te praten over een informatiesysteem als alle relevante informatie direct door eigen waarneming kan worden verkregen. De behoefte aan en de inrichting van een geautomatiseerd informatiesysteem is een functie van de hoeveelheid te verwerken informatie. Voor één of twee auto's is geen informatiesysteem nodig. Voor de kentekenregistratie in Veendam wel. Het is zelfs zo dat de omvang zeer complicerend werkt op het te ontwikkelen informatiesysteem. Het registreren van kentekens is een relatief eenvoudige zaak. Voor vier miljoen auto's wordt die eenvoudige registratie al knap ingewikkeld. De opzer van een informatiesysteem is dus (mede) een functic van de omvang wan de te verwerken gegevens. Omdat het in het MKB meestal over kleinere hoeveelheden te verwerken transacries gaat, wijkt de aanpak dus per definitie af van ondernemingen met zeer veel transacries. Voor leiders zijn deze transactiegerichte informatiesystemen belangrijk; deze 
leveren de grondstof voor het inzicht in de lopende of afgelopen activiteiten. Over het algemeen zullen zij er zelf weinig rechtstreeks gebruik van maken.

\section{Kantoorinformatiesystemen}

Dit type systemen behoort ook tot de operationele informatiesystemen, maar heeft een ander doel dan de systemen die de dagelijkse transacties ondersteunen.

Kantoorinformatiesystemen ondersteunen met behulp van (computer)netwerken de communicatie in een onderneming. Hierbij kan gedacht worden aan tekstverwerking, elektronische post zowel intern als extern, koppeling van de persoonlijke computers thuis en op kantoor, archieffuncties, enzovoort. Om deze moderne vorm van communicatie te doen slagen is het van belang dat ook leiders zijn aangesloten op deze interne en externe netwerken. Het moge duidelijk zijn dat het voor veel infonulle leiders moeilijk of onmogelijk is goed met anderen elektronisch te communiceren.

\section{Kennis- en expertsystemen}

Informatiesystemen die kennis gebruiken om met behulp daarvan bepaalde problemen op te lossen, worden kennissystemen of kennisgebaseerde systemen genoemd.

Als deze kennis wordt gemodelleerd op de wijze waarop menselijke experts werken, worden deze informatiesystemen expertsystemen genoend. Er zijn ook auteurs die kennis- en expertsystemen als synoniemen beschouwen (Prerau, 1990). Kennissystemen zijn voortgekomen uit het onderzoek naar kunstmatige intelligentie. Getracht wordt bij dit onderzoek menselijke intelligentie na te bootsen met machines. Het oudste en bekendste onderzoek op het gebied van kunstmatige intelligentie zijn schaakprogramma's (Van den Herik, 
1988). Veel expertise van organisaties zit alleen in de hersenen van mensen. Wanneer zo'n expert het bedrijf verlaat, sterft een deel van de kennis uit. In de afgelopen jaren is gebleken dat er veel toepassingen zijn, waarvan men destijds aannam dat deze te specialistisch waren om geautomatiseerd te worden en die toch inmiddels machinaal kunnen worden uitgevoerd. Niettemin verwacht een futuroloog als Makridakis (1989) dat het waarschijnlijk nog wel honderd jaar zal duren voor er sprake is van echte kunstmatige intelligentie. Computers, of beter gezegd programma's die de plaats innemen van experts of samenwerken met experts, komen mondjesmaat op de markt. Vooral in de medische wereld zijn er voorbeelden van geslaagde expertsystemen (Bonnet, 1987), maar er zijn slechts enkele commerciële toepassingen bekend." Volgens Makridakis is een algemeen gebruik van expertsystemen binnen vijftien jaar waarschijnlijk, waardoor een verregaande substitutie van kantoor-en dienstverlenend personeel zal plaatsvinden.

Er zijn auteurs die verwachten, dat er nooit expertsystemen op de markt komen, die leiding kunnen geven aan bedrijven of bedrijfsonderdelen dan wel in belangrijke mate daaraan ondersteuning kunnen leveren. Anderen menen dat juist de combinatie van beslissingsondersteunende systemen en kennissystemen wel degelijk van groot nut kan zijn voor leiders (Klein, 1990).

\section{Strategische informatiesystemen}

De laatste jaren wordt in toenemende mate gesproken en geschreven over strategische informatiesystemen. Hiermee bedoelt men de informatiesystemen die rechtstreeks verband houden met de (verbetering van de) bedrijfsprestaties (Parker, 1988). Veelvuldig wordt daarbij het voorbeeld aangehaald van een Amerikaanse toeleverancier aan ziekenhuizen, die zijn 
afnemers beeldschermen of andere eindstations ter beschikking stelde waarmee zij rechtstreeks bestellingen konden doorgeven (Wiseman, 1985). Door deze actie, gesteund door het informatiesysteem dat de communicatie met de afnemers kon verzorgen, werd in korte tijd een groot stuk van de markt veroverd. Sindsdien zoekt menigeen naar ideeën en mogelijkheden om de produkten respectievelijk de wijze van de aanbieding daarvan te ondersteunen met informatiesystemen. Activiteiten van ondernemingen die strategisch van aard zijn en reeds geruime tijd ondersteund worden door computers, worden momenteel gepromoveerd tot strategische informatiesystemen. Op de vraag of een onmisbaar financieel informatiesysteem dan niet strategisch zou zijn, kan men moeilijk ontkennend antwoorden, omdat het ontbreken daarvan immers ook de continuiteit van de onderneming op het spel zet. Dat neemt niet weg dat er bepaalde combinaties zijn van produkten en diensten met. informatie(systemen), die tot omzeten/of winstvergroting kunnen leiden. ${ }^{10}$

Dit geldt niet alleen voor grote ondernemingen. Ook de kleine tot zeer kleine ondernemingen hebben baat bij deze innovarie. " Kenmerk van deze systemen is echter dat zij alleen grote voordelen geven als de concurrentie deze innovatie nog niet toepast, of anders gezegd dat het bedrijf behoorlijke schade kan oplopen als de concurrentie deze systemen eerder met succes toepast. Strategische informatiesystemen zijn derhalve geen systemen, die veel door leiders worden toegepast, maar meer systemen die door leiders en zijn medewerkers worden bedacht en/of gestimuleerd. Leiders (en ondernemingen) zijn zeer gebaat bij het introduceren van succesvolle strategische informatiesystemen. De volgende generatie leiders zal voor het zoeken naar en implementeren van dergelijke systemen beter opgeleid en voorbereid zijn dan de zittende managers. 


\section{Documentaire informatiesystemen}

Steeds meer informatie die vroeger om economische en techmische redenen alleen maar in boekvorm beschikbaar was, wordt momenteel elektronisch toegankelijk gemaakt. Voor die informatieverzamelingen die niet voortdurend bijgewerkt behoeven te worden, komen relatief goedkope oplossingen op de markt, die deels ook toepasbaar zijn binnen het MKB. Hierbij valt te denken aan woordenboeken, encyclopedieën, treintijden (de Nederlandse Spoorwegen geeft niet alleen een floppy disk uit met tijden, maar ook enige ondersteunende programmatuur) en vliegtijden, foto-archieven, telefoonboeken, catalogi, enzovoort. Vanaf één compact disc kunnen langs optische weg honderden miljoenen gegevens worden gelezen. Behalve snel en goedkoop opzoeken van gegevens, bestaat ook het voordeel om geselecteerde gegevens over te nemen en verder te gebruiken in dynamische informatieverzamelingen. Sommige systemen kunnen ook voor leiders van belang zijn. Zeker de infofiele leiders zullen her op prijs stellen binnen een oogwenk de beschikking te hebben over miljarden gegevens die zij gewoon via hun persoonlijke computer kunnen raadplegen.

\subsection{Leiders en hun eigen informatiesystemen}

Leiders hebben om hun functic en/of roeping goed te kunnen vervullen informatie nodig. Informatie is voor hen de grondstof voor bouwblokken, die voortdurend worden onderzocht op nieuwe rangschikkingen, waardoor oplossingen in zicht kunnen komen. Voor een deel is dat informatie die zij oppikken in gesprekken, uit de krant, van de Tv, enzovoort. In toenemende mate komt die informatie uit computers. De systemen die dit mogelijk maken, worden Management Support Systemen of Executive Support Systemen genoemd. ${ }^{12}$ 
Dit zijn verzamelnamen voor verschillende soorten informatiesystemen ten dienste van de leiding, zoals management, executieve en beslissingsondersteunende informatiesystemen. Deze informatiesystemen hebben onderling gemeen dat zij zich richten op het leveren van adequate informatie voor het nemen van beslissingen voor het besturen van de organisatie en het ondersteunen van het uitvoeren van de taak als leider. De vraag is hoe verschillend deze systemen wel zijn. Vaak gaat het alleen om accent- en/of vormverschillen en hebben nieuwe woorden een commerciële achtergrond. Op de meest voorkomende benamingen wordt hier kort ingegaan.

\subsubsection{Management informatiesystemen (MIs)}

Bij dit type systemen gaat het om het verzamelen en verwerken van regelmatig voorkomende gegevens en het op een gestructureerde wijze van rapporteren daarover aan de leiding. Als het gaat over interne bedrijfsgebeurtenissen en situaties, wordt die informatie afgeleid van operationele informatiesystemen. Omdar die informatiesystemen traditioneel worden opgezet per subsysteem, dus een systeem voor personeel, voor produktie en voor verkoop, is het vaak een probleem geintegreerde informatie te produceren. Soms worden voor het management speciale programmas geschreven om die geïntegreerde informatie op te leveren. Deze methode van informatievoorziening aan topmanagers wordt de bij-produktrechniek genoemd (Rockart, 1979).

Als het gaat om gegevens die niet afgeleid kunnen worden van operationele systemen in de organisatie, zoals politieke gegevens of gegevens over de concurrentie, ontstaat de behoefte aan management informatiesystemen, die speciaal voor leiders worden ontwikkeld, gevoed en onderhouden. ${ }^{13}$ Volgens een onderzoek van de Universiteit Leuven besteden 
topmanagers van goed georganiseerde ondernemingen drie kwart van hun tijd aan dit soort externe gegevens.

\subsubsection{Executieve informatiesystemen (EIs)}

Management informatiesystemen is een besmet woord. Het herinnert ons warschijnlijk te veel aan de talloze mislukte pogingen in de jaren '60 en '70 om deze systemen tot een succes te maken (Heller, 1985).

Onder de naam Executive Information Systems (EIS) brengt een klein aantal bedrijven een informatiesysteem op de markt, waarin de integratie van gegevens van verschillende bedrijfssectoren voorop staat. ${ }^{14}$ Andere kenmerken zijn koppelingen met externe gegevensbanken, dynamische rapportering en een groot bedieningsgemak. Dat gemak gaat zover dat er een klein numeriek toetsenbordje voor de leider beschikbaar is om de informatie op te roepen. Men gaat er kennelijk van uit dat de meeste topmanagers angst hebben voor of weerstand hebben tegen alles wat met computers te maken heeft. Dit soort analfabetisme is van voorbijgaande aard. Voor zover we er op korte termijn niet in zullen slagen dit analfabetisme afdoende te bestrijden, sterft het uit. Onze toekomstige leiders, die nu in opleiding zijn, krijgen het werken met de computer met de paplepel ingegoten.

Executieve informatiesystemen zijn wellicht een voorloper van besturingskamers, waar de directie op en in de muur (koosnaam: Wally) beeldschermen laten monteren. Daar worden dan de directievergaderingen gehouden en bedrijfssituaties gesimuleerd. 


\subsubsection{Beslissingsondersteunende informatiesystemen (Bos)}

Het is maar welke definitie je afspreekt. Sommigen zien Bos'en beginnen waar management informatiesystemen eindigen. Anderen zien een Bos als een onderdeel van een MIS of andersom.

Bij dit type informatiesystemen ligt de nadruk op het ondersteunen van de leiding bij het nemen van specifieke beslissingen. Deze beslissingen kunnen zowel strategisch, tactisch als operationeel wan aard zijn. ${ }^{15}$ Van belang zijn faciliteiten in de zin van "wat gebeurt er als we ...".

Het gaat niet om beslissingen die geheel geautomatiseerd kunnen worden, zoals bijvoorbeeld het bestellen van artikelen op grond van een bepaalde voorraadpolitiek.

Bos'en onderscheiden zich van management informatiesystemen en operations research/management science oplossingen qua doel, aard en aanpak van de ontwikkeling (Keen, 1978). Er zijn Bos-ontwikkelgereedschappen nodig om Bos-applicaties te maken (Sprague,1982). Een bekend voorbeeld van een Bos-applicatie ${ }^{16}$ is een systeem waarmee portfolio-managers dagelijks beslissingen nemen over investeringen met de aan hen toevertrouwde gelden van hun klanten. Nier alleen grote ondernemingen kunnen profiteren van dit soort informatiesystemen. Ook voor kleine bedrijven kunnen deze systemen van grote waarde zijn. We mogen verwachten dat te zijner tijd informatiesystemen ontstaan, waarin deze beslissingsondersteunende systemen gecombineerd worden met kennissystemen gericht op het geven van leiding (Klein, 1990). 


\subsubsection{Persoonlijke informatiesystemen}

We moeten niet de vergissing maken dat het bij speciale informatiesystemen voor leiders alleen gaat om strategische zaken. Voor het uitwoeren van zijn verplichtingen als leider gaat het vaak om informatie van veel simpeler aard.

Vaststaat dat iedere manager een of andere vorm theeft van eigen informatieverwerking. Hij communiceert in woord en geschrift, hij maakt afspraken, hij heeft meestal een hele lijst van zaken die hij nier wil vergeten. Hij will bepaalde gegevens, rapporten, brieven, enzovoort bij de hand hebben.

Een leider neemt net zoals andere functionarissen voortdurend beslissingen over de wijze waarop hij zijn tijd besteedt. We kunnen dat moeilijk strategische beslissingen noemen. Een (top)manager beschikt daarvoor meestal over een zeer flexibel informatiesysteem, te weten zijn secretaresse. Verder zijn er in grote ondernemingen stafmedewerkers, die vragen kunnen beantwoorden. Dit is valk een moeilijk te verwezenlijken zaak voor een MKв-leider.

Een goede oplossing kan zijn het op een juiste manier leren een persoonlijke computer (PC) te gebruiken. Het is lastig. gebleken managers vooraf te overtuigen dat zij op andere wijze (met een PC) hun werk beter kunnen uitvoeren. Discussies over deze zaken, zowel met managers als met hun medewerkers, worden vaak emotioneel.

Helaas hebben computers een negatieve klank gekregen en is een persoonlijke compurer een anti-statussymbool geworden, vooral omdat gebruikers zijn gedwongen te veel onnatuurlijke handelingen te verrichten.

Een probleem is dat er geen eenduidige manier bestaat om managers te laten werken met het nieuwe gereedschap. In de praktijk is gebleken dat de managers die met succes persoonlijke computers gebruiken, dat elk op hun eigen manier doen. Daarbij passen zij algemene of specifieke tekstverwerkings- 
programmatuur, spreadsheetsprogramma's, grafische programma's, informatie-opslagprogramma's, enzovoort op hun eigen wijze toe.

\begin{tabular}{|c|c|c|c|}
\hline \multirow[b]{2}{*}{ soort informatiesysteem } & \multicolumn{3}{|c|}{ GEBRUTK } \\
\hline & $\begin{array}{l}\text { niet } \\
\text { door } \\
\text { leiders }\end{array}$ & $\begin{array}{l}\text { mede } \\
\text { door } \\
\text { leiders }\end{array}$ & $\begin{array}{l}\text { alleen } \\
\text { door } \\
\text { leiders }\end{array}$ \\
\hline transacriegerichte systemen & $x$ & & \\
\hline kantoorinformatiesystemen & & $x$ & \\
\hline kennis-en expertsystemen & $x$ & & \\
\hline strategische informatiesystemen & $x$ & & \\
\hline documentaire informaticsystemen & & $x$ & \\
\hline management informatiesystemen & & & $x$ \\
\hline executieve informatiesystemen & & & $\mathrm{x}$ \\
\hline beslissingsondersteunende systemen & & $x$ & \\
\hline persoonlijke informatiesystemen & & $x$ & \\
\hline
\end{tabular}

Figuur 3: Overzicht informatiesystemen in relatie tot gebruik door leiders

\subsection{MKB-leiders en informatiesystemen}

MKB-leiders zijn vaak directeur/eigenaar. In veel gevallen zijn zij ook de oprichter. In familiebedrijven ontstaan leiders vaak door exfenis. Ook in het MKB kunnen we de metaforen on- 
dernemer, aanvoerder en beheerder onderscheiden. In het MKB zullen echter relatief meer ondernemers en dus infonullen voorkomen. Naarmate de onderneming kleiner is, zullen er minder gesystematiseerde informatiesystemen nodig zijn en zeker geen volledig geautomatiseerde. Goed gebruik van standaardprogrammatuur zorgt vaak al voor acceptabele oplossingen. De informatievoorziening voor een MKB-leider moet ook zijn afgestemd op zijn niveau. Het heef geen zin hem van informatie te voorzien die hij niet begrijpt. Dat geldt overigens ook voor leiders van grote organisaties, zij het dat die er minder voor uitkomen als zij iets niet weten of begrijpen. Er zijn een aantal verschillen en overeenkomsten tussen een leider in het MKB en zijn collega van een (zeer) grote onderneming. Beiden dragen eindverantwoordelijkheid. Een MKB-leider heeft meestal een lagere opleiding. Hij is zowel verantwoordelijk voor het te voeren beleid als voor de uitvoering. Bij de zeer kleine ondernemingen voert hij in veel gevallen zelf een aantal persoonlijk uit. Hij heeft weinig of geen hulp van interne specialisten. Een мкв-leider moet dus zeker een doener zijn, maar aan de andere kant voldoende strategisch inzicht hebben om met zijn bedrijf meer succes te hebben dan zijn concurrent.

Ook onder MKB-leiders komen prototypen van ondernemers, aanvoerders en beheerders voor. De zogenaamde 'combi-'leiders kunnen een klein bedrijf uitbouwen naar een groter bedrijf. Er zijn maar enkele mensen op aarde die in staat zijn geweest om een klein bedrijf te leiden naar een zeer groot bedrijf. ${ }^{17}$ Op de weg van een bedrijf van geen naar bijvoorbeeld $10,20,50$ en 100 miljoen omzer zijn meestal verschillende leiders nodig (Clifford, 1986).

Er is verder geen enkele reden om aan te nemen dat er zich onder MKB-leiders geen depressieve, dramatische en achterdochtige managers zullen bevinden. De invloed van een MKBleider op her niet of wel, en in welke vorm en mate, automa- 
tiseren is evenwel nog belangrijker dan in grote ondernemingen. Bij de behandeling van de aanpak van het automatiseren van informatiesystemen voor het MKB wordt op deze materie nader ingegaan. 


\section{Informatie- en automatiseringsbeleid}

\subsection{Bestuurlijke informatiekunde}

Hoe komen leiders aan informatiesystemen voor zichzelf en hun organisatie? In deze oratie is tot nu toe voornamelijk aandacht besteed aan het doel van geautomatiseerde informatiesystemen en de rol van de leiders hierbij, en nog niet aan de besluitvorming over het well of niet automariseren, de mate en de vorm van een eventuele automatisering. In dit hoofdstuk komt het kiezen van de gewenste geautomariseerde informatiesystemen aan de orde, met name de verschillen daarbij tussen grote en kleine organisaties. Het kiezen van informatiesystemen staat niet op zichzelf, maar vormt een onderdeel van een informatie- en automatiseringsbeleid. Ook hiervoor dienen keuzen gemaakt te worden. Voor het MKB is een methode uitgewerkt, die als ondersteuning kan dienen bij het bepalen van het automatiseringsbeleid.

Buiten het kader van deze oratie vallen belangrijke onderwerpen als het ontwikkelen, onderhouden, gebruiken en beheren van informatiesystemen, hoewel deze onderwerpen in het vak Bestuurlijke Informatiekunde aan de Rijksuniversiteit Limburg wel aan de orde komen.

Informatiekunde is een berrekkelijk nieuw woord. ${ }^{18}$ In de van Dale van 1984 komt het woord nog niet voor. Ook in de van Dale van 1990, die wordt uitgegeven op een compact disc, is het woord informatiekunde nog niet opgenomen. In de jaren '60 spraken we nog niet over bestuurlijke informatiekunde, 
maar over (administratieve) automatisering. De benadering in die periode was sterk apparanurgericht. Het ontwikkelen van informatiesystemen verkeerde toen nog in een pioniersfase. De opdrachtgevers in die tijd waren meestal niet tevreden met de resultaten van de automatiseringsinspanningen. Wat dat betreft is er niet veel veranderd. Eind jaren ' 60 en begin jaren ' 70 werd steeds meer gesproken over informatica. Hiermee werd mede aangeduid dat een meer fundamentele aanpak van de automatisering werd nagestreefd. Toch bleef de nadruk bestaan op de techniek, maar nu de techniek van het programmeren en opslaan van gegevens. Scheidingen tussen informatietechniek, informatica en informatiekunde zijn niet scherp te trekken. Met het nieuwere woord informatiekunde bedoelen we de kennis en vaardigheid met betrekking tot het organiseren, structureren van gegevens tot informatie los van de technische hulpmiddelen waarmee dat gebeurt. Informatiekunde wordt vaak gericht op vernieuwing in een bepaald vakgebied. Zo zou je kunnen praten over medische, juridische en agrarische informatiekunde.

Bij bestuurlijke informatiekunde gaat het specifiek om het organiseren, structureren van gegevens tot informatie ten behoeve van het besturen van organisaries. Bestuurlijke informatiekunde ligt dus dicht bij organisatiekunde en bestuurskunde. Het is een goede zaak als een verdere integratie tussen deze vakken en bestuurlijke informatiekunde wordt nagestreefd (Tas, 1986; Heijnsdijk, 1989).

De ontwikkeling van de automatisering is weergegeven in figuur 4 . 


\begin{tabular}{|l|l|l|}
\hline jaren: & toepassing van: & accent op: \\
\hline 60 & auromatisering & apparatum \\
80 & informatica & programmaruur \\
80 & informatiekunde & informatie \\
90 & organisariekunde & bedrijp \\
\hline
\end{tabular}

Figuur 4: Toepassing van informatietechnologie in de jaren $60-90$

Veel informatiekundigen concentreren zich op het vinden van methoden en technieken voor het structureren van informatiesystemen. Er zijn inmiddels meer dan driehonderd methoden gepubliceerd, die aangeven hoe informatiesystemen het beste kunnen worden gebouwd. ${ }^{19}$ Het is duidelijk dat er geen methode is die voor elke situatie geschikt is. Niet alle driehonderd methoden zijn volledig en nauwkeurig. In feite missen de meeste een wetenschappelijke onderbouwing (Nijssen, 1989). De laatste jaren woeden er Hoekse en Kabeljouwse twisten over deze methoden. We moeten hierbij in acht nemen dat veel methoden worden gepubliceerd om commerciële redenen. Een groot automatiseringsbedrijfkan zich bijna niet meer permitteren geen eigen methode te hebben waarmee het zich goed kan onderscheiden van andere. Het bouwen van informariesystemen wordt vaak vergeleken met het bouwen van huizen. Er wordt dan gewezen op de opgebouwde kennis van vele eeuwen en de nauwkeurigheid waarmee deze projecten worden gepland en uitgevoerd. Wie echter te maken heeft gehad met het (ver)bouwen van zijn eigen huis, zal zich ongetwijfeld zijn irritatie herinneren over de moeiza- 
me manier en het te late tijdstip, waarop ook de laatste ongemakken en kleine gebreken worden verholpen. Nieuwe projecten zoals de Stopera, Deltawerken en de Amsterdamse metro zijn ook niet bepaald voorbeelden van een beheersmatige aanpak. De duizenden jaren ervaring met bouwen van gebouwen kan dus niet model staan voor het bouwen van informaticsystemen.

Bestuurlijke informatiekunde richt zich niet alleen op de informatievoorziening van leiders. In de hele organisatie op alle niveaus bestaat behoefte aan informatie om de onderneming te laten functioneren en verantwoording te laten afleggen. Het vak Bestuurlijke informatiekunde richt zich op het bepalen en bevredigen van die informatiebehoeften. Dat dit bij een economische faculteit moet gebeuren in her licht van een juiste afweging van kosten en baten, ligt voor de hand.

\subsection{Aanpak in (zeer) grote ondernemingen}

Er is een groot verschil in het leiden van grote en kleine organisaties. Deze stelling gaat ook op voor de aanpak van de automatisering van de bestuurlijke informatieverzorging. Er gelden verschillende criteria voor wat groot en klein is. Voor banken wordt naar het balanstotaal gekeken. Het kleinste bankje in Nederland heeft een balanstotaal van $f 30$ miljoen. Voor winkelbedrijven is het vloeroppervlak de maatstaf en voor agrarische bedrijven het aantal hectaren grond. Bij industriële en handelsbedrijven wordt ook vaak gekeken naar het aantal personeelsleden. Klein is dan 1 tot 10 , middelgroot 10 tot 100 en groot meer dan 100 (Keuning, 1989). Superbedrijven zijn ondernemingen met meer dan 1000 medewerkers.

Uiteraard zijn deze aantallen arbitrair, maar de indeling in klassen is ook voor de benadering van informatiesystemen 
goed bruikbaar, zij het dat het zinvol is om daarvoor de middelgrote bedrijven nog verder onder te verdelen in een aantal klassen, omdat de verschillen tussen ondernemingen van 10 , 20,50 en 100 medewerkers onderling zeer groot zijn. De verschillen spitsen zich toe op leiderschapstijl, organisatiestructuur, (on)ontwikkelde administratieve organisatie, (deels) ontbreken van middenkader en ondersteunende interne diensten, ervaring en kennis, eigendomsverhoudingen, enzovoort. De verschillen worden duidelijk als dieper wordt ingegaan op zaken, die wel bij grote organisaties een belangrijke rol spelen en niet bij her мкв en omgekeerd.

\subsubsection{Informatietechnologie}

Zeer grote bedrijven hebben vrijwel allemaal een relatief lange automatiseringshistorie achter de rug. De bellangrijkste systemen zijn waak al enkele keren opnieuw gebouwd. Meestal omdat zich weer een nieuwe technologie aandiende, die meer en betere mogelijkheden bood casu quo leek te bieden. In deze bedrijven gaat het er vandaag de dag om hoe er een goede visie kan worden ontwikkeld voor de acceptatie en verspreiding van de huidige en nieuwe informatietechnologie. Zij zijn op zoek naar de werkelijke en misschien wel strategische waarde van informatiesystemen. Het besef is aanwezig dat deze zaken samenhangen met organisatiecultuur, leiderschapstijlen, bedrijfsplanning en organisatiebeleid, en tal van andere zaken; praktische handvatten om een geïntegreerd beleid daarvoor te ontwikkelen ontbreken echter meestal. Zoals bij veel kwesties in grote bedrijven speelt zich ook een machtstrijd af over de zeggenschap over de automatiseringsmiddelen. De volgende vragen geven voldoende aanleiding voor comperentiekwesties. Wie is bevoegd te investeren? Wie bepaalt de prioriteiten? Wie is eigenaar van het informatiesys- 
teem? De strijd om de macht speelt zich af in een driehoek met de leider, het automatiseringsopperhoofd en de lijnmanagers als hoekpunten.

\subsubsection{Machtsdriehoek}

De lijnmanager, bijvoorbeeld een directeur van een bedrijfseenheid, vraagt zich af waarom het toch zo moeilijk is om die informatiesystemen te leveren, die hij zo hard nodig heeft. Hij heeft weinig begrip voor de vaak zeer grote achterstand van de automatiseringsafdeling als gevolg van personeelsproblemen en uit de hand gelopen onderhoudswerkzaamheden. Onbegrijpelijke rekeningen van het rekencentrum over onnavolgbare prestaties maken het niet beter. Deze lijnmanagers vormen een belangrijke doelgroep voor de software-industrie, die al of nier bewust te optimistische perspectieven voorspiegelt als de automatiseringsproblemen worden uirbesteed. De praktijk in Nederland is echter dat het merendeel van de opdrachtgevers ontevreden is met de geleverde prestaties door de computerservice-industrie. ${ }^{20}$

Het hoofd wan de automatisering vindt dat de grote ervaring van het computercentrum met informatiesystemen altijd. moet worden gebruikt. Interne automatiseringsfunctionarissen brengen de volgende argumenten naar voren om de macht over de automatiseringsmiddelen in handen te houden of te krijgen. "Bewaking van procedures en standaards krijgt minder aandacht wanneer de verantwoordelijkheid voor automatisering wordt verdeeld onder lijnmanagers." "Wie kan nu beter beslissen over zelf maken of kopen dan het computercentrum?" "Beveiliging gaat bovendien beter vanuit één centraal punt." 
De leider van de onderneming vraagt zich af, of hoort dat althans te doen, of de gelden voor de informatietechnologie (IT) adequaat worden besteed, of zijn IT- en andere managers nog wel bij de tijd zijn, hoe goed of slecht het is bepaalde ontwikkelingen te volgen of na te laten, of de automatiseringsmiddelen voldoende zijn gespreid in zijn organisatie, of de invloed op de aanwending van de informatietechnologie evenwichtig is verdeeld (Cash, 1988).

\subsubsection{Portfolio-analyse}

Als de competentiekwesties die in grote organisaties spelen, zijn opgelost, blijft de vraag hoe het beste objectief kan worden vastgesteld welke informatiesystemen beter wel of niet moeten worden geautomatiseerd.

$\mathrm{Er}$ is sterke behoefte aan kwantitatieve methoden om een keuze te onderbouwen. Bedell heeft een methode gepubliceerd, waarin het bouwen, kopen, uitbreiden en afschaffen van informatiesystemen wordt gezien als (des)investeringsbeslissingen en waarmee op min of meer op rekenkundige wijze wordt aangegeven of ge(des)investeerd moer worden in bepaalde informatiesystemen (Van Reeken, 1988). De uitkomst hangt uiteraard sterk af van de betrouwbaarheid waarmee de gebruikte parameters kunnen worden ingevuld. Het type informatiesystemen waaraan zeer grote bedrijven toe zijn, is zeer verschillend van die van vroeger. Het is nu moeilijker zo niet onmogelijk om de pay-out van de systemen te berekenen.

Een andere methode (Cash, 1988) om her kiezen te vereenvoudigen is het afwerken wan een checklist per project, waarin vragen over kosten, opbrengsten, risico's en dergelijke worden gewogen met vuistregels uit de praktijk. Op die manier kan het belang van een te bouwen informatiesysteem worden uit- 
gedrukt in cijfers, waardoor onderlinge vergelijking met eventucel andere te bouwen informatiesystemen mogelijk wordt.

\subsection{Aanpak in kleine ondernemingen}

De problematiek van kleine bedrijven met betrekking tor de informatietechnologie verschilt dus aanzienlijk van die van zeer grote ondernemingen. Evenzeer geldt dat voor de oplossingen.

Let wel: er wordt niet ontkend dat het wezen van informatie hetzelfde is in grote en kleine bedrijven; evenmin wordt ontkend dat bepaalde informatiestructureringsmethoden of programmeringsmethoden niet zouden overeenkomen. Er wordt alleen gesteld dat deze zaken voor het MKB niet interessant zijn. Kleine bedrijven komen nier aan de vraag toe op welke wijze hun systemen het beste ontwikkeld kunnen worden. Zij zitten wel met de vraag of (beperkte) investeringen met betrekking tot automatiseren wel of niet moeten gebeuren.

Leiders in het мкв zitten met het probleem dat zij daarin zelf moeilijk een keuze kunnen maken. Zij moeten daarom terugvallen op (externe) adviseurs. In het MKB bestaat niet veel bereidheid gebruik te maken van (dure) adviseurs. Meestal worden de kosten van het advies afgewogen tegen het bedrag dat een eventuele investering met zich meebrengt. мкв-leiders voelen er weinig voor om $f 25.000$,- aan advieskosten uit te geven als de (hele?) automatisering bijvoorbeeld f $30.000,-$ kost.

De technologie is inmiddels zover gevorderd dat zeer kleine bedrijven met een dergelijk budget een oplossing kunnen bereiken voor tal van administratieve problemen. Dat de schade van een verkeerde automatisering soms een weelvoud kan bedragen van de geplande investering, spreekt de meeste MKB- 
leiders niet aan. Er is derhalve een behoefte aan een eenvoudige methode, die MKB-leiders in staat stelt zelf, dan well met enige hulp van derden, snel een goede richting te bepalen. Er is nog betrekkelijk weinig onderzoek verricht naar het bepalen van informatie- en automatiseringsbeleid in het MkB. De theorie en praktijk van informatica en informatiekunde is voornamelijk afgestemd op grote organisaties. Het is bepaald onvoldoende om die kennis - al of niet vereenvoudigd - van toepassing te verklaren voor her MKB.

Het мкв kent zijn eigen problematiek en de benaderingen zullen daarop moeten worden toegespitst. Veel мкв-leiders hebben weinig affiniteit met administratie, administratieve organisatie en automatisering, laat staan met het informatiebeleid als onderdeel van de strategie van de onderneming. Aan de andere kant heeft het MK. grote voordelen ten opzichte van grote organisaties, die het automatiseren en informatiseren sterk vereenvoudigen, simpel omdat het gat om weinig mensen. Het overleg gaat sneller en effectiever, de besluitvorming is eenvoudiger en in korte tijd kunnen belangrijke beslissingen genomen worden. Verder heeft her MKB weinig last van historische ballast, hetgeen wil zeggen dat meteen met betrouwbaardere middelen aan de slag kan worden gegaan. De specifieke situarie van het Mкв stelt ook specifieke eisen aan de automatisering. Naast goedkoop moet de oplossing ook vriendelijk zijn voor leiders en gebruikers. De kwaliteit van de oplossing moet hoger zijn, want het MKB heeft geen eigen staf om fouten op te lossen. Het verhaal dat programma's nooit vrij zijn van fouten, gaat er daar niet in. Omdat MKB-leiders vaak ook eigenaar zijn, voelen zij de investeringen en uitgaven in hun eigen zak. Leveranciers van automatiseringsdiensten en -produkten kunnen niet rekenen op goodwill als hun leveranties niet perfect zijn.

Deze perfectie is eenvoudig te bereiken wanneer standaardprogramma's duizenden keren worden verkocht en gebruikt. 
Moeilijker wordt het als bedrijfseigen programmatuur moet worden vervaardigd voor het MKB. Deze fase breekt inmiddels aan. Dat betekent dat het MKB geen genoegen meer neemt met uitsluitend (Amerikaanse) standaardprogramma's. Ook het MKB gaat een periode tegemoet, waarin een simpele automatisering van de boekhouding wordt vervangen door complexere financiële systemen, waarbij losse systemen voor acquisitie, verkoop, order- en voorraadverwerking, distributie, facturering en financiële afwerking worden vervangen door geintegreerde informatiesystemen.

Uiteindelijk zullen ook management support systemen deel gaan uitmaken van de programmatuur voor het мкв. Voor industriële bedrijven liggen er nog extra kansen door toepassing van intelligente robots, die een deel van de produktie zullen overnemen. Veel ondernemingen in het MKB zullen te maken krijgen met externe koppelingen met leveranciers, klanten en banken. Zeker MKB-toeleveranciers aan grote ondernemingen zullen onder druk staan om de gegevensuitwisseling te uniformeren en te automatiseren.

Geavanceerd automatiseren lukt pas nadat op elementaire basis kennis en ervaring is opgedaan. Bij het uitstippelen van de route voor de toekomst moet hiermee rekening worden gehouden.

\subsubsection{TOBI-methode}

Bij de Rijksuniversiteit Limburg wordt onderzoek verricht naar de criteria die een bellangrijke rol spelen bij de besluitvorming over automatisering binnen het $\mathrm{MKB}^{2 !}$

Op dit moment gaan we uit van een model waarin de antwoorden op een reeks vragen een globale aanzet voor het automatiseringsbeleid aangeven. 
De vragen worden verdeeld in vier categorieèn, te weten vragen over Technologie, de Ondernemer, het Bedriff en de Interactie met de omgeving. Op deze manier ontstaat een naam voor de methode: товr.

Alle vragen en categorieèn hebben wegingsfactoren, die voorlopig op grond van ervaringen van specialisten worden toegekend, maar op den duur vervangen moeren worden door via fundamenteel onderzoek verkregen cijfers. Ook de oplossingen worden in vier categorieën ingedeeld. De rol van de leider wordt vrijwel doorslaggevend naarmate het bedrijf kleiner is.

De eerste oplossing is Tijd brengt raad. Voor de ondernemingen die in deze categorie vallen, is eigenlijk geen enkele automatiseringsoplossing mogelijk, anders dan vervanging of herprogrammeren van de ondernemer. Als het goed gaat met zo'n onderneming, is dat toevallig.

De tweede categorie oplossingen wordt aangegeven met Organisatorische voorbereidingen, zoals het opleiden van de leider en wellicht één of meer medewerkers. Verbeteringen in de organisatie hebben bij deze categorie een groter effect dan op uitgebreide schaal te gaan automatiseren. Het aanschaffen van een persoonlijke computer voor bijvoorbeeld enkele geisoleerde taken die eenvoudig met behulp van goedkope softwarepakketten uitgevoerd kunnen worden, kan deel zijn van het voorbereidingsproces. 


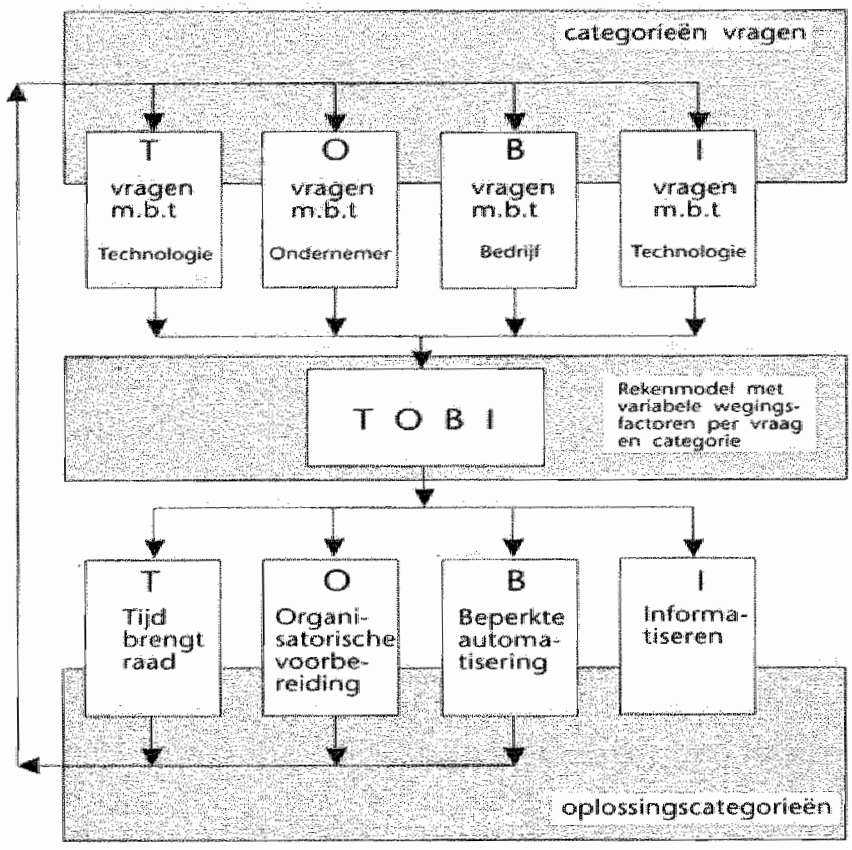

Figuur 5: TOBI-methode voor het MKB

De derde categorie oplossingen is Beperkte automatisering. Deze bedrijven zijn er aan toe om één automatiseringsproject wit te voeren. Dit project moer zorgyuldig worden gelkozen. Het mag niet te groot zijn en moet meteen resultaat opleveren. Als een en ander goed verloopt kan aan een volgend project worden begonnen. Verbeteren ook de organisatorische randvoorwaarden, dan kan dit bedrijf in de volgende categorie vallen.

De vierde categorie is Informatiseren. Voor deze meestal relatief grotere bedrijven binnen het MKB is her weggelegd 
volgens het 'boekje' te automatiseren (GrTP, 1989). De kosten die gemaakt moeten worden woor een uitgebreid onderzoek zijn verantwoord. ${ }^{22}$

De te stellen vragen in de verschillende categorieèn vormen nog object van studie. In figuur 6 zijn een aantal vragen geselecteerd, die belangrijk zijn voor het te bepalen beleid.

De vragen in de categorie o van ToBr slaan op de MkB-leider. Deze categorie vragen komt overeen net de aanbeveling voor grotere organisaties om een psycho-analyse van de leider en een relatie-onderzoek tussen leider en organisatie op te nemen als onderdeel van de bepaling van de informatiebehoefteanalyse voor leiders. De vragen aan en over de leider (ondernemer) hebben tot doel inzicht te krijgen in de opstelling van de leider ten opzichte van organisatie en informatie.

De score per vraag loopt van nul tot negen. Bij elke vraag hoort een handleiding om de "score" van de vraag te kunnen bepalen. Elke vraag en elke categorie hebben een variabele wegingsfactor, die onder meer afhangt van de omvang van de onderneming. Het komt de objectiviteit van de waardering van de vragen ten goede als de leider deze vragen samen met een derde invult. 
(vereenvoudigde) TOBl-enquête

Gebruik wor het toekennen wan de score per vraag de

TOBT-handleiding $n \pi$ " voorbeeld"

Functie: directeur

Omvang: 21 medewerkers

Branche: industrie

Automatiseringsgraad:

$\mathrm{PC}$ voor administratie

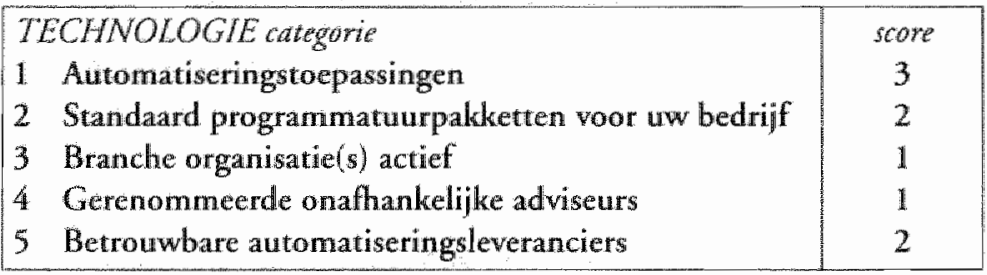

ONDERNEMER categoric

1 Houding naar procedures, regelingen

scone

2 Houding naar automatisering

3 Beschikbare tijd ondernemer/directeur

4 Budgettaire mogelijkheden

5 Verwachtingen over automatisering

BEDRIF categorie

1 Huidige administratieve organisatic

2 Projectleiding

3 Invloed op het bedrijfsgebeuren

4 Ervaring personeel in de toepassing

5 Bekendheid met automatisering

6 Financièle speelruimte

sore

8

4

7

8

6

7

INTERACTIE met OMGEVING cattegorie

1 Concurrenten

2 Leveranciers

3 Klanten

4 Overige te verwachten veranderingen

5 Relatie met produkt en/of dienstverlening

Figuur 6: (Vereenvoudigde) TOBI-enquête 
Het moge duidelijk zijn dat infofiele MKB-leiders hoog zullen scoren en derhalve waarschijnlijk met hun onderneming in een hogere oplossingscategorie terecht zullen komen. Op de vraag bijvoorbeeld naar de beschikbare tijd van de leider, gaat het erom vast te stellen of en hoeveel tijd hij zelf wil en kan besteden aan de begeleiding van het automatiseringsproces in zijn bedrijf. Hier bestaat en verband met affiniteit naar procedures, regelingen, administratieve organisatie en dergelijke. Als deze affiniteit laag is, beïnvloedt dat negatief de wegingsfactor van de vraag over de beschikbare tijd. Zou vervolgens op de vraag over de te verwachten tijdsbesteding 'veel' geantwoord worden, dan mag worden aangenomen dat dit een weinig betrouwbaar antwoord is respectievelijk dat de bestede tijd weinig doelmatig is. Een grote affiniteit met administratieve organisatie gecombineerd met de wil en de mogelijkheid om veel tijd te besteden versterken elkaar en leveren een maximale score voor de vraag over de tijdsbesteding. Als alle vragen zijn ingevuld, rekent het model aan de hand van de verschillende wegingsfactoren het rosr-getal uit. Dit getal geeft de graad aan van de oplossing. Een zeer lage score betekent niet automatiseren en misschien zelfs niets doen. Een zeer hoge score betekent dat leider en onderneming met een redelijke kans op succes aan een geavanceerd beleid op het gebied van de informatietechnologie kunnen denken.

\subsubsection{Wie gaat het mks helpen?}

\section{De rijksoverheid en provinciale overheden}

Het is duidelijk dat het MKB behoefte heeft aan ondersteuning om met vrucht gebruik te kunnen maken van de huidige en toekomstige informatietechnologie. De overheid ziet dat ook in gezien de vele stimuleringsmaatregelen die zich expli- 
REKENMODEL TOBI-GETAL

\begin{tabular}{|c|c|c|c|c|c|}
\hline & & $\begin{array}{l}\text { Functie: } \\
\text { Omvang: } \\
\text { Branche: } \\
\text { Autonatiser } \\
\end{array}$ & $\begin{array}{l}\text { financieel di } \\
21 \text { d } 50 \mathrm{~m} \\
\text { industrie } \\
\text { ingsgraad: } \\
\text { geautomatis } \\
\text { adm. }\end{array}$ & $\begin{array}{l}\text { Brecteur } \\
\text { Bedewerk } \\
\text { Boekd PC } \\
\text { erd }\end{array}$ & \\
\hline Technologie & $s c$ & gewicht & gewogen & $\begin{array}{l}\text { relatiewe } \\
\text { score }\end{array}$ & 1 \\
\hline Automariseringstoepassingen & 3 & 2 & 06 & & \\
\hline Stand programmatuurpak. & 2 & 3 & 06 & & \\
\hline Branche organisatie(s) & 1 & 1 & 01 & & \\
\hline Gerenomraeerde adviseurs & 1 & $\mathbb{1}$ & 01 & & \\
\hline Betrouwbare aut - leveranciets & 2 & 2 & 04 & & \\
\hline & rocaal 09 & $\max 81$ & 018 & 22 & \\
\hline Ondernemer & $s c$ & c. gewich & gewogen & $\begin{array}{l}\text { relatieve } \\
\text { score }\end{array}$ & 6 \\
\hline Houding nar procedures & 7 & 3 & 21 & & \\
\hline Houding naar automatisering & 8 & 2 & 16 & & \\
\hline Beschikbare tijd ondern./dit. & 4 & 5 & 20 & & \\
\hline Budgertaire mogelijkheden & 8 & 3 & 24 & & \\
\hline Verwachtingen & 7 & 2 & 14 & & \\
\hline & totaal 34 & $\max 135$ & 095 & 70 & \\
\hline Bedrijf & sc & gewicht & gewogen & $\begin{array}{l}\text { rellatieve } \\
\text { score }\end{array}$ & 4 \\
\hline Huidige adm. organisatie & 8 & 5 & 40 & & \\
\hline Projectleiding & 4 & 5 & 20 & & \\
\hline Invloed bedrijfsgebeuren & 7 & 4 & 28 & & \\
\hline Ervaring personeel & 8 & 3 & 24 & & \\
\hline Bekendheid automarisering & 6 & 2 & 12 & & \\
\hline Financiêle speelruimre & 7 & 3 & 21 & & \\
\hline & totaal 40 & $\max 198$ & 145 & 73 & \\
\hline
\end{tabular}




\begin{tabular}{|lcccc|c|}
\hline Interactie met omgeving & sc gewicht gewogen relarieve & 2 \\
Concurrencen & & & & & \\
Leveranciers & 2 & 1 & 02 & \\
Klanten & 7 & 4 & 28 & \\
Overige veranderingen & 6 & 2 & 12 & \\
Produkt eniof dienstwerlening & 6 & 3 & 18 & \\
& 4 & 5 & 20 & \\
\cline { 2 - 6 } & total 25 & $\max 135$ & 080 & 59 \\
\hline
\end{tabular}

\begin{tabular}{|l|l|l|}
\hline TOBI-getal & 65 & Advies: beperkte bedrijfsautomarisering \\
\hline
\end{tabular}

Figuur 7: (Vereenwoudigd) rekenmodel woor bet bepalen van bet TOBI-getal

ciet richten op het мкв. Hierdoor wordt een infrastructuur gecreëerd, waarin het MKB profijt kan trekken van de moderne hulpmiddelen. Te denken valt hierbij aan subsidies voor management en organisatie- en automatiseringsadviezen, innovatieprojecten, de oprichting van adviescentra gericht op het MKB en het ontwikkelen van branche informatieraamwerken (BIR), die de basis kunnen vormen van branchegerichte pakketten.

\section{Adviseurs}

Verder onckomen ondernemingen in het $\mathrm{MKB}$ niet aan een professionele begeleiding op essentiele momenten in de ontwikkeling van het bedrijf. Zo'n moment is het bepalen van de automatiseringsstrategie. De TOBI-methode kan hierbij helpen, maar als her gaat om de aanschaf van (de eerste) automatiseringhulpmiddelen, lijkt professioneel en vooral onafhankelijk advies onontbeerlijk. Hierbij kunnen de door de overheid gestimuleerde adviescentra, waarvan de stichting 


\section{Computerservice-industrie}

Na het strategisch advies kan het bedrijf in hoge mate zelf en met enige steun van de automatiseringsleverancier aan de slag. De MKB-bedrijven die zich in de derde en vierde oplossingscategorie bevinden, hebben echter meer op maat gesneden programmatuur en ondersteuning nodig. Het overgrote deel van de computerservice-industrie is niet ingesteld op de bediening van het MKB. Dat komt door de historische ontwikkeling van die tak van industrie en de huidige kostenstructuur (Mulder, 1990).

\section{Goed opgeleide medewerkers}

Automatiseringsfuncrionarissen met een middelbare beroepsopleiding op het niveau informatica/informatiekunde kunnen uitstekend voldoen aan de behoefte in het мкв. Met moderne ontwikkelgereedschappen zijn MBO-ers thans reeds in de praktijk bezig specifieke informatiesystemen op maat te ontwikkelen (Mulder, 1990).

ExIN, het Nationaal Exameninstituut voor Informatica, heeft een goed initiatief genomen met de ontwikkeling van praktijkexamens informatica op MBO-niveau, de zogenaamde PDIexamens. Deze specificaties zijn - ook in het reguliere onderwijs - enthousiast ontvangen.

Het belang van MBo-ers in de automatisering werd al eerder onderkend door de overheid. In dic verband wordt gewezen op het Isi-project, het Instroomproject Schoolverlaters Informariseringsberoepen. De doelstelling van dit project, gestart in 1985, was om in enkele jaren 15.000 cursisten op te leiden voor informatiseringsberoepen op middelbaar niveau. De doelstelling is vrijwel gehaald. Deze мво-ers hebben voor het overgrote deel hun weg gevonden op de arbeidsmarkt, waarbij ruim $60 \%$ is terechtgekomen in het MKB. Een groot deel 
van de ISI-cursisten is betrokken bij de ontwikkeling van automatiseringstoepassingen. ${ }^{23}$

Voor specialistische en/of complexere problemen kunnen organisaties in het MKB een beroep doen op externe ondersteuning. Dat zullen over het algemeen professionals zijn met een hogere beroeps- of wetenschappelijke opleiding. Met deze laatste categorie houdt onder meer de Rijksuniversiteit Limburg zich bezig. Naast het bijbrengen van een wetenschappelijke attitude is er hier open oog voor dat onze studenten moeten functioneren in groepen, bedrijven en andere organisaties. Het in Maastricht gehanteerde systeem van probleemgestuurd onderwijs ondersteunt in belangrijke mate deze doelstelling. 


\section{Afsluiting}

Voor iemand die grotendeels in de praktijk is gevormd, is het werken op een universiteit een bijzondere ervaring. In de dagelijkse praktijk van het leidinggeven is er vaak onvoldoende rijd om de zaken zo gedegen en in alle rust te onderzoeken als op een universiteit. Veel besluiten moeten met alle bijkomende emoties soms zeer snel worden genomen. Deze gang van zaken zal in veel gevallen het leidinggeven blijven typeren. Dat betekent dat als universiteiten oplossingen en handvatten willen aanreiken aan organisaties en hun leiders, zij deze omstandigheden zoveel mogelijk in acht moeten nemen en derhalve met praktische en haalbare oplossingen moeten komen. Die inbreng zou ik graag proberen te geven aan onze universiteit, met name voor de onderwerpen die vandaag aan de orde zijn gekomen.

Veel mensen ben ik grote dank verschuldigd voor de hulp die ik van hen mocht ontvangen. Daarbij denk ik aan mijn gezin, familie en vrienden in het bedrijfsleven en collega's aan de universiteit. In het bijzonder dank ik prof. Bert van 't Kloos-

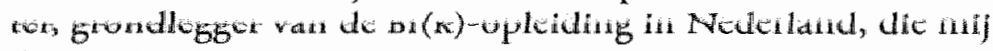
de weg heeft gewezen en Klaas van der Heide die mij daarbij door dik en dun heeft gesreund. Jan Roosingh wist mij in de laatste 20 jaar steeds weer opnieuw te stimuleren nieuwe invalshoeken te onderzoeken, een rol die ook Ton van Reeken de laatste jaren vanuit de Rijksuniversiteit Limburg heeft gespeeld. Mijn collega’s prof. Bram Beek, prof. Jan Dietz en prof. Sijir Nijssen dank ik voor hun hulp en geduld. 
Tenslotte wil ik het bestuur van de Stichting Bijzondere Leerstoel Bestuurlijke Informatica, in het bijzonder de voorzitter, mr. drs. M.A.K. Snijders en de toegevoegd secretaris, de heer ing. O.W.J. Quint, danken voor hun vertrouwen en daadwerkelijke steun. 


\section{Geraadpleegde literatuur}

Awad Elias M., Management Information Systems, The Benjamin Cummings Publishing Company lnc, California, 1988

Badaracco Jr Joseph L., Ellsworth Richard R., Leadership and the Quest for Integrity, HBS Press, Boston, 1989

Beck A., Informatisering in het Midden- en Kleinbedriff. Informatie, jaargang 31 , nr 1, 1989

Bennis Warren, Nanus Burt, Leaders, Harper \& Row, Publishers, New York, 1985

Blake R.R., Mouton J.S., Leiderschapspatronen (vert.) Markaboek 89, Het Spectrum, Uerecht, 1968

Blanchard Kenneth., Peale Norman Vincent., Management of Ethiek, Veen, Utrecht, 1988

Bonnet Alain, Kunstmatige Intelligentie (vert.), Addison Wesley Nederland, Amsterdam, 1987

Bots J.M., Heck E. van, Swede V. van, m.m.w. Simons J.L., Bestuurlijke Informatiekunde, Cap Gemini Publishing, Rijswijk, 1990

Capra Fritjof, Leadership, ISC-Invernational Management, proceedings of a management seminar, St. Gallen (Sw), 1985

Cash Jr James I., McFarlan F: Warren., McKenney James L., Corporate Information Systems Management, The Issues Facing Senior Executives, Irwin, Homewood, 1988/2

Clifford Jr Donald K., Cavanagh Richard E., Ondernemen om te wizinen, The Winning Performance, Veen, Utrecht, 1986

Curtis Graham, Business Information Systems, Addison-Wesley, 1989

Dietz J.L.G., Zo gezegd, wo gedalan, oratie Rijksuniversiteir Limburg, Maastricht. Academic Service, Schoonhoven, 1990

Dissel H.G. van, Park David, Informatiebeteds-evi Informatieplanningsmethoden, Informatic 89-110, bly, 748-758

Dreesmann Anton C.R. Entreprenetarship and leadership, in: Leadership, 15 th International Management Symposium, Saint Gallen Graduate School, Swizzerland, blz 65-70, 1985 
Drucker Peter F., The Fromtiens of Management, Heinemarn, London, 1987

Finkelstein Clive, An introduction to information engiweering. AddisonWesley, 1989

Galbraith Jay R., Het ontwerpen vats complexe orgarnisaties. Samsom Alphen a/d Rijn, 1988

GITP/Managemenc Advies, ea., Bedrijfinformatie, satap woor stap naar betere resultatem, Samson, Apthen aan den Rijn, 1989

Haaren S.J.M. van, J.P. Schuurman, Administratieve dutomatisering in het MKB, Hoofdbedrijfschap Ambachten, HBA-reeks nr 51, 1987

Handy Charles, The Gods of Management, Pan Books, 1985

Heijnsdijk J., Vitale Organisaties, Wolters-Noordhoff, Groningen, 1988

Heller R., Het geheim wan de excellente manager, Veen, Urrecht, 1985

Heller R., De naakte manager, Veen, 1985

Hellriegel Don, Slocum J. John W., Management 5th, Addison- Wesley, 1989

Herik H.J. van den, Informatica en bet menselijke blikveld, Rijksuniversiteit Limburg, Maastricht, 1988

Hicks Jr James. O., Management Information Syotems, a user perspective, West Publishing Co., St. Paul, 1984

Hopstaken B.A.A., Burg ter R.P., Kranendonk A., Trends in Automatisering, Stenfert Kroese, Leiden, 1988

Hussain Donna, Hussain K.M., Information Processing Syntems for Management, Richard D. Irwin. Inc., Homewood, Illinois, 1985/2

Hussain Donna, Hussain K.M., Information Resource Managemert, Richard D. Irwin, Inc., Homewood, Illinois, 1984

Iacocca Lee., Novak, William., Lacocca, Een Amerikanse Carrìre, Mingus, Baarn, 1985/5

Isenberg Daniel J., How senior managers think, Harvard Business Review, nov/dec 1984

Jackson Ivan F., Corpomate Information Management, Prentice-Hall, Englewood Cliffs, New Jersey, 1986

Keen Peter G.W., Scott Morton Michael S., Decision Suppport Systems. an organizational perspective, Addison-Wesley Publ. Co, Inc., 1978

Kets de Vries Manfred F, De F-Factor, Veen, Utrecht, 1989

Kets de Vries Manfred F, Miller Danny, Balanceren aan de top, Sijthoff, Amsterdam, 1988

Keuning D., Bedrijfskunde, Stenfert Kroese, Leiden, 1989 
Kein Miche] en Merhlie Leif B., Expert systems, a decision support approach, Addison-Wesley, 1990

Kotter John $\mathbb{P}$, What effective general managers really do, Harvard Business Review, nov/dec 1982

Kotter John P., What leaders really do, Harvard Business Rewiew, mei/juni 1990

Makridakis Spyros, Management in the 21st Century, Long Range Planning, april 1989

McFarlan F. Warren, The Information Systems Research Challenge, proceedings of a research colloquium, Harvard Business School Press, Boston, 1984

Menting Henri B.J., Organisatiecultum en informatiesystemen, Stenfert Kroese, Leiden, 1989

Minuberg Henry, The nature of managerial work, Prentice Hall, 1973

Mulder Th. J., Informatica op MBO-nivean, Tr-forum, mei 1990

Mulder Th. J., Automatisering in de negentiger jaren, Quote, december 1989

Nijssen G.M., Grondldagen wan Bestwurlijke InformatieSystemen, Nijssen Adviesbureau voor Informatica, Slenaken, 1989

O'Leary T.J., Williams Brian K., Computers and Information Systems, The Benjamin Cummings Publishing Company Inc, California, 1989

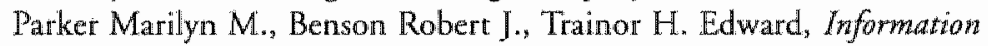
Economics, Linking business performance to information technology, Prenrice-Hall Int., London, 1,988

Peters Thomas J.. Austin Nancy K., De dynamiek van het ondernemen, Veen, Utrecht, 1986

Peters Thomas J., Waterman Jr Robert H., Excellente ondememingen, Veen, Utrecht, 1988

Peters Tom., Handboek voor Revolutionair management, Veen, Urrecht 1989

Peters Tom., Austin Nancy, A Passion for Excellence, Warner Books, New York, 1986

Poursma E., e.a., Automatisering: effecten toor bet MKB, Economisch Instituut voor her MKB, Zoetermeer, dec. 1986

Poutsma $\mathrm{E}$., Automatiseringsprocessen in kleinere bedrijuen, Economisch Instituut voor het MKB, Zoetermeer, dec. 1986

Poutsma E., Zward A., Procesinnovatie door automatisering in bet MKB, Mandblad Informatie 1989 nr 3 
Recken A.J. van, Investeringsulectie win Informatiegyzemens (De methode van Bedell), Beleidsinformatica Tijdschrifr, volume 14 n 41988

Reeken A.J., De owtwikkeling wan de informatiesystemontwikkeling, G1100 in Oonincx et al (EDS.): Automatisering van de informatieverzorging, Samsom, Alphen aan de Rijn, losbladig, april 1988

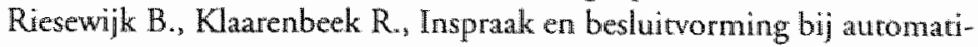
seringsprojecten, IT-Forum, jan 1990, blz 6-9 en 15

Rockart John F., Chief executives define their onn data needs, Harvard Business Review maart-april 1979, blz $81-93$

Riesewijk en Warmerdam, Atutomatiseringsprojecten; slagen of falen, Ministerie van Sociale Zaken en Werkgelegenheid, Den Haag, 1988

Schein Edgar $\mathrm{H}_{\text {. }}$, Corporate teams and rotems Sloan Management Review, winter 1989

Schotgerrits A.H.J.B., e.a., Ondernewnen met Informatie Technologie, Samsom, Alphen a/d Rijn, 1989

Schuurman J.P., Een branchegewijze aanpak wan awwomatisering binnen bet $M K B$, Maandblad Informatie 1989 nr 3

Siskens W.J.A., Heemstra F.J., Stelt H. van der, Kostenbeheersing bij automatiseringsprojecten, een empirisch onderzoek, Maandblad Informatie 1989 nr 1

Sprague Jr Ralph H., Carlson Eric D., Building Effective Decision Support Systems, Prentice Hall, New Jersey, 1982

Starreveld R.W., Leer watn de administratieve organisatie, Samsom, Alphen aan den Rijn, 1966

Starreveld R.W., Mare H.B. de, Joëls E.J., Bestuurlijke informatieverzorging deel 1, 2e (herziene) druk, Samsom, Alphen aan den Rijn, 1989

Starreveld R.W., Mare H.B. de, Joëls E.J., Bestuurlijke informatieverzarging deel 2, 3 e druk, Samsom, Alphen aan den Rijn, 1989

Tas P.A., Informatickunde op waarde geschat, Kluwer, Deventer, 1986

Tichy Nod L., Devanna Mary Anne, De transformationele manager, Sijrhoff, Amsterdam, 1987

Timmons Jeffry A., Entrepreneurship in the 1990s, Irwin, Boston, 1990 Waterman Jr Robert H., Verniewwing als strategie, Veen, Utrecht, 1988

Wiseman Charles, Strategy and Computers, Information Systexns as Competitive Weapons, Dow Jones-Irwin, Homewood, 1985

Zaleznik Abraham, Mandgement of disappointment. Harvard Business Review, nov/dec 1967

Zaleznik Abraham, Managers and leaders, are they differene? Harvard Business Review, mei 1977 


\section{Noten}

1 Hoewel het leidinggeven niet specifiek is voorbehouden aan mannen, zijn er - nog - aanzienlijk meer mannelijke leiders dan vrouwelijke. Derhalve is over mannelijke leiders meer bekend. Vaak wordi aangegeven dat men voor 'hij' ook 'zij' mag lezen. In zijn algemeenheid wordt opgemerkt dat het denkbaar is dat wrouwelijke leiders cen andere informatiebehoefre zullen hebben.

2. Amerikarnse succesverhalen hebben een standaard recept. Een klein aantal essentièle opmerkingen worden gelardeerd met een hele reeks prakrijkwoorbeelden. Naast onderzoekers doen ook de succeswolle leiders er zelf aan mee. (Heller 1985, lacocca 1985, McCormack 1989, Peters/Waterman, 1986,1988 en 1989, Tichy 1987.)

3 Aan de Faculteiten der Economische en Algemene Wetenschappen van de Rijksuniversiteit Limburg wordt over een breed front onderzoek verricht op gebieden die te relateren zijn aan één of meer groorheden van het 7-S model van McKinsey. In deze oratie is dat Stijl van leidinggeven en informatieSystemen. Bij de oprichting van de faculteit is vastgelegd, dat men zich wil concentreren op drie aandachtsgebieden, te weten de conomie var de arbeid, de economie wan de technologische ontwikkeling en de economie van de publieke sector.

Onderzock wordt verricht door onder meer de volgende collega's:

- prof. A. Beck: onderzock naar (administratieve) organisarie en informatiesystemen, Hoofllypen wan de administratieve organisatie, J. Lam en A. Beek, 4e druk, Wolters-Noordholf, Groningen, 1988

Hoofligmen wan de administratieve automatisering, W. Leijnse en A. Beek, 3e (herz.) druk, Wolters-Noordhof, Groningen, 1989 
- prof. dr. ir. J.L.G. Dietz: onderzoek naar het modelleren en formeel specificeren van informatiesystemen in natuurlijke taal, Modelleren en specificeren wan informatiesystemen, proefschrift, 1987

- prof. H.J. van den Herik: onderzoek naar kunstmatige intelligentie en informatiesystemen. Computerschaak, schaakwereld en kunstmatige intelligentie, Academic Service, 1983

- prof. dr. J.F. den Herrog: onderzoek naar technologische vernieuwing en psychologie van arbeid en organisatie, Management wan technologische vernieuwing, Van Gorcum, Assen/Mastricht, 1990

- prof. dr. G. Hofstede: onderzoek naar cultuur in relatie met (internationale) organisaties en samenleving, Culture comsequences: international differences in wark-related values, Beverly Hills (erc.): Sage Publications, 1987

- prof. dr. J.D.P. Kasper: onderzoek naar de verbanden tussen de organisatiecultuur en marketingstrategie, Marketing en constementensouveremiteit, een ondorzoek nadar de invloed van consumentenklachtery op de strategie van de onderneming vU Boekhandel, Amsterdam, 1982

- prof. dr. E.J.J.M. Kimman: onderzock naar de ontwikkelingen van ethiek in de samenlleving en bedrijven. Deugden in de directiekamer, Serie Economische Ethick $\mathrm{Nr}$ 2, Van Gorcum, Assen/Maastricht, 1989

- prof. dr. ir. A. Kolen: onderzock naar kunsmatige intelligentietoepassingen op het gebied wan produkrieplanning, naat planning en scheduling van Alexibele produkriesystemen en naar ontwerp en beslissingsondersteunende systemen.

- prof. dr. ir. G.M. Nijssen: onderzoek naar informatie-analyse op basis van de natuurlijke talal, Grondslagen van de Bestwurlijke InformatieSysternen, Nijsen Adviesbureau voor Informatica BV, Slenaken, 1989

- prof. dr. J.M. Pennings: onderzoek naar innovatie en effectiviteit van organisaties en de relaties met hun omgeving, Strate gy and organizational design. Pitman, Marstifield, 1990

- prof dr. J.H.R. v.d. Poel: onderzoek naar menselijke informatieverwerking en informatiesystemen, Judgment and cantrol: individual and organizational aspects of performance evaluation. Wolters-Noordhoff, Groningen, 1986 
- prof. dr. H. Schreuder: onderzoek naar de samenhang cussen organisatiekenmerken structuur: culcuur en control. The structure of orgenizations: a conceptual and empirical assessment of Mintaberg's typology. H. Schreuder (et all. Faculty of Economics, Limburg Universiry, 1989, De economische inbreng in de strategrebepaling van ondernemingen: een overzicht. $\mathrm{P}$ van $\mathrm{Cay}$ seele en H. Schreuder, Faculteit der Economische Wetenschappen, Rijksuniversiteir Limburg, 1988

4 In 1979 publiceerde John Rockart in Harvard Business Review enkele methoden wan informatiebehoefiebepaling voor topmanagers. Als serieuze methode werd de 'nul-aanpak' toegelicht. Uitgangspunten waren de dynamische en steeds veranderende acriviteiten, waardoor het onmogelijk zou zijn teworen te zeggen welke informatie nodig is. De informatie waaraan behoefte is, is voor een groot deel afkomstig van specularies, gevoel, intuïtie, roddels, enzovoort. Naast nadelen van deze methode werd als voordeel genoemd de besparing wan de ontwikkeling van nutteloze informatiesystemen.

5 Manfred F.R. Kets de Vries is hoogleraar Human Resources aan her Europees Instituut voor Business Administration. Hij was daarvoor hoogleraar aan de McGill University, Ecole des Hautes Etudes Commerciales (Montreal) en de Harvard Business School. Hij is ook praktizerend psycho-analist. Zijn onderzoek richt zich op de relatie tussen psycho-analyse, dynamische psychiatrie en management.

6 De klassieke school heeft wel een antwoord: POSDCORB! Een leider Plant, Organiseert, kiest zijn Staf, Dirigeert, Coördineert, Rappor teert en Budgetteert.

Onderzoekers als Drucker en Mintzberg zijn hier nier tevreden mee, omdat dit allerminst specificeert wat een leider echt doet.

7 In Informatie 89-10 wordt door Van Dissel en Park verslag gedaan wan een literaruuronderzock naar Strategische Informatiebeleidswormings- en informatieplanningmethoden (SIPMen). De conclusie luidr dar de bekende methoden zoals Business Systems Planning (BSP), Information Engineering (IE), Critical Success Factor (CSF) en Strategic Systems Planning (SSP) nog ernstige tekorkomingen bevatten. 
8 Onderzoeken naar de resultaten van grotere betrokkenheid van de hoogste leiding bij automatisering zijn wooral uitgevoerd bij grotere organisaties. Daar werd positieve correlatie ontdekt russen de betrokkenheid van de hoogste leiding bij automatisering en de resultaten daarvan. Ook bij de honderden projecten die systeemhuis Multihouse in de jaren '70 en ' 80 uirvoerde bij middelgrote organisaties, is vastgesteld dat belangstelling bij de hoogste leiding van opdrachtgevers een gunsrige invloed had op de projecten.

9 Digital kent een expertsysteem voor het samenstellen van computerconfiguraries. Bij CGE word gewerkt aan een expertprogramma voor het stellen van een diagnose van technische storingen.

10 Systemen die de verkoop kunnen aanwakkeren zijn de zogenaamde Marketing en Sales Productivity (MSP) systemen. Hierover werd in Harward Business Review gerapporteerd in februari 1989 (blz. 100108) door Moriarty en Swartz. De onderzochre bedrijwen die een MSP'systeem hadden geinstalleerd, toonden een stijging van de verkoop tussen de 10 en $30 \%$.

11 Een voorbeeld van een strategisch systeem voor een slagerij zou kunnen zijn een informatiesysteem waarin de banten zijn opgenomen met hun gezinssamenstelling, eventuele dieetvoorschriften, voorkeur en dergelijke. De slager heeft dan de mogelijkheid op maat gesneden menu's te maken horende bij een bestelling. Dit is een vorm van persoonlijke service, die tot klantenbinding en -werving zal leiden. De concurrende slagers uit da buurt zullen het merken.

12 Vanwege de 75 e verjaardag van de Harvard Business School werd in het academisch jaar $1983 / 1984$ een research colloquium gehouden, waaraan vele prominenten uit de Amerikaanse universitaire wereld. en het bedrijfsleven deelnamen. Doel was de research programmas wan deze universiteiten uit te wisselen. Het re onderzoeken veld werd verdeeld in management support systemen, technologic van informatiesystemen en organisacie, management van automatiseringshulpmiddelen, technologie van informatiesystemen en corporate strategie, alsmede de research strategieën van de verschillende aanwezige Business Schools. 
13 Een methode die externe, interne, harde en zachre informatie combineert is de Critical Success Factor-methode, de CSF-ampak, ontwikkeld door Sloan School of Management Massachusetts Institute of Technology (Rockart, 1979).

14 In de Automatiseringsgids wan 14 februari 1990 wordt vermeld dat er volgens een onderzoek van Amdahl minder dan 200 executieve informatiesystemen in Europa in gebruik zijn. Als voorbedden van dir soort systemen worden genoemd: Metapraxis en Pilot. In Informatiemanagement van april 1990 zijn resultaten van een onderzoek gepubliceerd over EIS'en, uitgevoerd door Van der Toorn en Pillar (TU Delft). Ondetrocht zijn Pilot en Commander.

15 En interessante benadering van her type beslissingen is uitgewerkt in Decision Support Systems (DSS) van Keen en Morton (1978). Zij combineren de theoric van Simon over gestructureerde, semi- en niet-gestructureerde beslissingen met de theorie van Anthony over de verschillende niveaus van leiding.

16 Een ander voorbeeld van een BOS is her systeem dac de politie van San Jose, California heeft ontwikkeld om de slagkracht te vergroten als het gaat om onmiddellijk te reageren op een overval, gijzeling, en dergelijke. Het systeem voorziet de diensudoende officier van informatie over de omgeving, relevante telefoonnummers, activiteitenniveaus, enzovoort. Verder voorziet het systeem in toegespitste informatie op grond van door de politiefunctionaris in te brengen parameters.

17 Ken Olson is een woorbeeld van een man die mede-oprichter was van Digital Equipment Corporation. In dertig jaar leidde hij de organisatie naar een omvang van ruim 125.000 personeelsleden en een omzat van $f 25$ miljard, behald in 59 landen (Financieel Dagblad van 12 januari 1990 ).

18 Het begrip 'bestuurlijke informatiekunde' wordt voor het eerst gebruikt door prof. J. wan Belkum in 'Inhoud en structuur van het vakgebied bestuurlijke informatiekunde", Limperg Institunt, werkgroep Terminus, mart 1982. 
19 Van Reeken (1988) heeft rachtig methoden voor her ontwikkelen van informatiesystemen in kaart gebracht, die in Nederland worden toegepast.

20 Onderzocken wan Riesewijk en Warmerdam in 1988, her onderzoek in opdracht van Nokia Data door het Instituut voor Sociale Kommunikatie in 1989, alsmede het onderzoek van Siskens, Heemstra en Van der Srelt in 1989 wijzen in de richring van relarief veel mislukte en problemarische projecten.

21 Op 31 mei 1989 heeft de Rijksuniversiteit Limburg samen met cen aantal andere organisaties een seminar georganiseerd voor het Midden-en Kleinbedrijf onder de titel 'Automatisering in het MKB, een noodzaak. Tijdens het congres werd de TOBl-methode toegelicht en konden de deelnemers anrwoord geven op een aantal geselecteerde vragen. De antwoorden werden tijdens het seminar verwerkt en gepresenteerd. Iedere deelnemer kreeg een 'persoonlijke' brief met een globaal advies op basis van de TOBI-methode. Het Adviescentrum Automatisering Limburg en de Rijksuniversiteit Limburg breiden de TOBI-methode werder uit en doen veldonderzoek bij het Limburgse MKB.

22 Een benadering die specifiek voor dit type bedrijven is ontworpen, is ontwikkeld door GITP/Management Advies, begeleid door NIVE, NCD, NIRIA, KIVI, NIBIN en Management opleidingscentrum Stichting Baak. Dir is een handboek bestemd woor directeuren van het industriële MKB; het geeft op overzichtelijke wijze aan hoe een informatie-en automatiseringsplan kan worden opgezer voor bedrijven van de derde en vierde categorie.

23 Over her 15I-project, Instroomproject Schoolverlaters Informatiseringsberoepen, zijn inmiddels acht voortgangstapporten versehenen afkomstig van het $\mathrm{PCAB}$, Pedagogisch Centrum Beroepsonderwijs Bedrijfsleven. Het achuste rapport dateert van augustus 1989. Het eindrapport wordt medio 1990 verwacht. 